
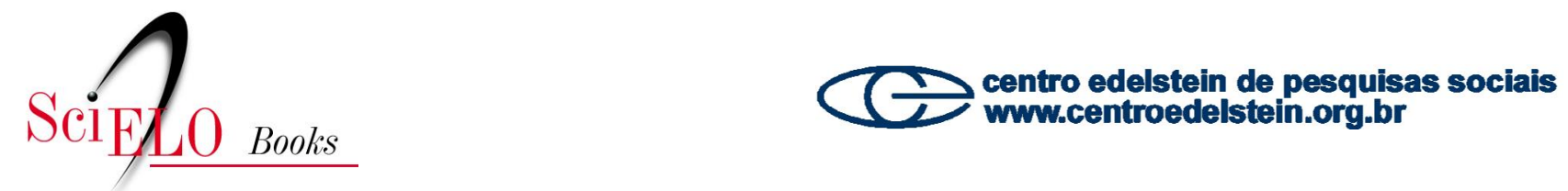

\title{
Latin America's elusive democracies
}

\author{
Bernardo Sorj
}

SORJ, B. Latin America's Elusive democracies [online]. Rio de Janeiro: Centro Edelstein de Pesquisas Sociais, 2007, 111 p. ISBN: 978-85-99662-21-2. Available from SciELO Books $<\underline{\text { http://books.scielo.org }>\text {. }}$

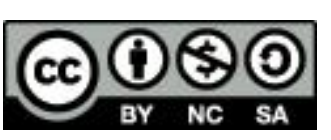

All the contents of this chapter, except where otherwise noted, is licensed under a Creative Commons Attribution-Non Commercial-ShareAlike 3.0 Unported.

Todo o conteúdo deste capítulo, exceto quando houver ressalva, é publicado sob a licença Creative Commons Atribuição Uso Não Comercial - Partilha nos Mesmos Termos 3.0 Não adaptada.

Todo el contenido de este capítulo, excepto donde se indique lo contrario, está bajo licencia de la licencia Creative Commons Reconocimento-NoComercial-CompartirIgual 3.0 Unported. 


\section{LATIN AMERICA'S ELUSIVE DEMOCRACIES}

Bernardo Sorj

Prologue by Guillermo O'Donnel E-books Series 2, May 2007 
This publication is part of The Virtual Library of Social Sciences of The Edelstein Center for Social Research - www.bvce.org

Copyright (C) 2007, Bernardo Sorj

Copyright (C) 2007 of this on-line edition: The Edelstein Center for Social Research

Prologue by Guillermo O'Donnell

Translated from the Spanish version: La democracia inesperada, Buenos Aires, Prometeo Libros, 2005

English Translation: Gretta Siebentritt

E-books Series 2, May 2007

No part of this publication may be reproduced or transmitted for commercial purposes in any form or by any means without permission in writing from the copyright holder at the address below. Parts of this publication may be reproduced for noncommercial purposes so long as the authors and publisher are duly acknowledged.

ISBN 978-85-99662-21-2

The Edelstein Center for Social Research www.centroedelstein.org

Rua Visconde de Pirajá, 330/1205

Ipanema - Rio de Janeiro - RJ

CEP: 22410-000. Brazil

Contact: bvce@centroedelstein.org.br 


\section{CONTENTS}

PROLOGUE: Guillermo O'Donnell. 4

INTRODUCTION: The Democratic Paradox 7

CHAPTER I: Citizenship and Human Rights ..........................................................13

The diverse forms of citizenship .................................................................14

Citizenship and the antinomies of human rights .................................21

CHAPTER II: From Labor Rights to Minority Rights ...................................................28

The transition from labor contracts to social rights ...............................28

Social inequality, the market, and the State ..........................................36

From anonymous domination to fragmented rights .............................41

The new individualism and collective identities ......................................44

The crisis of political representation and the role of the Judiciary........53

CHAPTER III: “Civil Society”, Nongovenmental organizations, and the

Globalization of Social Agendas .................................................................................58

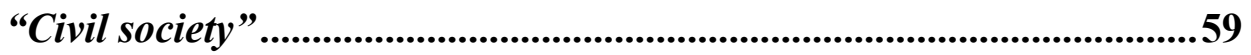

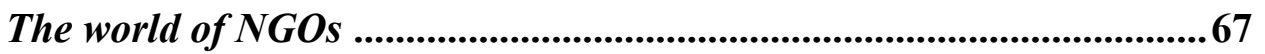

Reconstructing the world through human rights or the market?...........75

International public opinion and national governments .......................82

CHAPTER IV: Social transformations and the Judicialization of

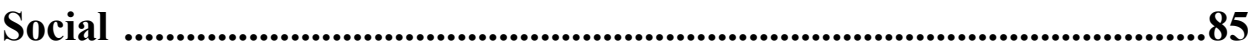

Citizenship in Latin America: variations on modernity............................87

Notes on Latin American individualism ................................................92

CONCLUSIONS: Politics without Morals and Morals without Politics? ....................97

Challenges for democracy .............................................................99

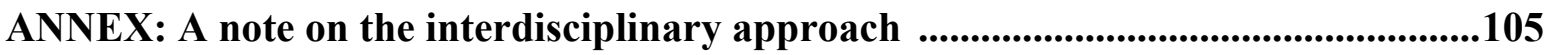

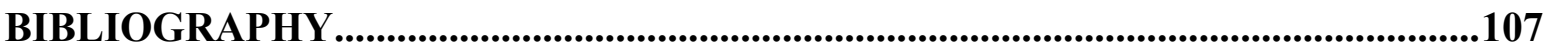




\section{PROLOGUE}

\section{Guillermo O'Donnell}

This is a refreshing book: it contains nothing trite, rejects conventionality and academic fads, and unswervingly asserts a clear position on thorny issues. With this book, Bernardo Sorj has demonstrated once again what those of us who have followed his career already knew: not only is he an excellent sociologist, but above all, he is a true intellectual, a critical thinker who tackles the main issues of today's world, and Latin America in particular.

Sorj begins with the typical question posed by intellectuals of his kind: "What times are these?" Obviously, this question casts our thinking in many different directions. But Sorj's quest is disciplined by a central thesis that gives meaning to the book's title ("The Unexpected Democracy" in the Spanish version, T.N.): "Democracy seems to have been consolidated, but it is not the democracy we expected." Although I am not sure I agree with the notion of "consolidation," this thesis frames a challenge that I share completely: in order to understand our countries and their democracies, we must first understand the nature of global changes and second, discern their specific manifestations in countries such as ours, with their oppressive legacy of poverty, inequality, and socially-entrenched authoritarianism. This is an enormous undertaking, one which Sorj approaches with lucidity and to which he makes important contributions.

In this undertaking, Sorj delves into various issues that I will refrain from summarizing here as they are articulated clearly in this book, which the author has had the prescience to keep short. I would, however, like to highlight a few points. The first is his reflection on the "dual difficulty" posed by the study of citizenship in the Latin American context and his incisive critique of numerous works (not only on citizenship) that approach this topic solely from the standpoint of how it deviates from the (idealized) image of citizenship in advanced capitalist countries. Here, Sorj is right on target (once again defying much of the literature in vogue) when he asserts 
a strong analytical and historical link between citizenship, on the one hand, and nation-people on the other.

A second point is that the notion of citizenship leads inexorably to that of rights, but Sorj argues convincingly that rights should not be understood only in the abstract, but also, and most importantly, in terms of how they interface with the specific characteristics of our societies. It is precisely those characteristics, as Sorj will argue throughout this book, that enable us to understand the current hypertrophy of certain rights, the acute breakdown of others, and in general, the judiciary's excessive involvement in adjudicating certain rights as the representative functions inherent to political parties have evaporated.

The third point I wish to stress is that in order to develop these analyses, it is necessary to accomplish—and accomplish very well-two inherently complicated tasks: fully grasp the theories relevant to the issues and understand the unique historical and social aspects of the cases under study so as to reconstitute those theories appropriately. The entire book reflects this, yet I would draw attention particularly to Chapter II ("From labor rights to minority rights") as a masterful application of this level of sophistication.

My fourth comment is that, as I alluded to earlier, we must thank Sorj for his willingness to take a balanced and critical look at the various idealized perspectives of civil society, nongovernmental organizations, and human rights. While he does not deny the importance of these spheres and their contributions, he does not hesitate to point out the errors-in theory and practice-resulting from the idealistic and moralistic postures that frequently go hand in hand with such perspectives. Similarly, with a particular and, in my opinion, completely justified critical edge, Sorj examines the various conceptions of social capital (particularly those of the World Bank).

These positions are openly controversial. But whether one shares them or not (and I share nearly all of them), the aim of this book is to spark debate. Sorj's mastery of theory and his informed excavation into the reality of our countries (not only Brazil, although that is the main reference point for this Uruguayan and 
"Rioplatense" whom the winds of repression deposited in Brazil some twenty years past) has exposed the many myths clouding our perceptions of the reality, and the potential, of our countries.

That is why I began this brief prologue by saying that this is a refreshing book. I hope it is now clear that I use the term as the highest praise that can only lead to the recommendation that it be read with a mind as open as the vigorous thinking of the author.

January 2005 


\section{INTRODUCTION - The Democratic Paradox}

This book discusses the end of one historic period and the beginning of a new era, which is still in its incipient stages; for this reason, it is difficult to pinpoint the main trends. Throughout the era now drawing to a close, which essentially coincides with the $20^{\text {th }}$ century, social classes played a central role in shaping political and ideological life. Throughout this period, social demands were organized as collective rights revolving around the workplace which the welfare state then extended to other sectors of society.

The vision of the world sustained upon a tripod—in which the social classes were the organizers of social structure, trade unions gave shape to workers' interests, and political parties articulated social utopias-is obsolete. The transformations of capitalism and the defeat of communism diluted the structuralizing role of social classes, diminished the importance of trade unions, and weakened political parties in general and leftist parties in particular.

Anti-liberalism cannot be used as an intellectual alibi to evade the question: what new times are these? This essay's response to that question is that we live in increasingly democratic societies in which egalitarian values are intensified, even as social inequity grows. The democratization of values and expectations through expanded communications systems, the consolidation of individualism and a consumer society, weakened social hierarchies, the strengthening of "civil society and the dissemination of the human rights discourse has fostered a sense of interdependence and common humanity among all residents of the planet. Nonetheless, democratic regimes are finding it increasingly difficult to address rising social and economic inequity and tackle burgeoning social problems, particularly violence and poverty. In Latin America, this contradiction has become particularly acute due to the expectations raised by democratization. 
Democracy seems to have beeen consolidated, but it is not the democracy the people expected. This essay explores the reasons behind this unexpected democracy by examining how it evolved in relation to social dynamics, individualization, the democratization of social relations, and changing mechanisms for political representation.

In order to understand contemporary trends, we must first understand exactly what has changed. The current situation essentially is the result of new patterns of individualization and the configuration of collective identities and forms of political participation that fragment social representation and undermine the capacity to develop proposals for transforming society as a whole. It is important to recognize the complexity of historical processes and demonstrate the unforeseeable and unintentional consequences of social action, without falling into a Manichean or conspiratorial view of history in which all roads lead to Washington and all new forms of creativity and social action are reduced to factors set into motion by the hegemonic power. ${ }^{1}$

Today's crisis of political representation is a byproduct of the widening gap between political parties and the NGOs - the new vectors of solidarity values-, of the emphasis on human rights discourse (coupled with the simplistic portrayal characteristic of the mass media), of the moralistic assertion of values dissociated from interests, and finally, of a purely market-centered discourse. Both the latter and human rights discourse exclude from political life the articulation of specific social and economic interests and their place in power structures.

"Civil society" and the new social actors construct their identities around human rights-related claims or demands driven by the constitutional system, NGOs, and international organizations, usually outside the political parties. While the

\footnotetext{
${ }^{1}$ This is true of many social scientists, some inspired by Pierre Bourdieu, who reduce any new form of social action to a process of perpetual returns for elites co-opted by the power system. It involves, in a way, a Paretean vision of history that, while presented in critical terms, is no less reactionary in that it is incapable of portraying historical changes. On the issue of human rights and Latin America from this perspective, see Yvez Dezalay, Bryant G. Garth, The Internationalization of Palace Wars Lawyers, Economists, and the Contest to Transform Latin American States, The University of Chicago Press, Chicago, 2002.
} 
accumulation of rights may reinforce a sense of dignity among the different groups, the outcomes of the demands brought forth by these new social actors have proven extremely ineffective in terms of reducing socioeconomic inequality in society as a whole.

The new forms of social participation organized around "non-socioconomic" causes, such as, for example, ecology, feminism, race, or ethnicity, are fragmented and lack a vision of national society. This undercuts the role of political party representation inasmuch as public policy is focused on increasingly splintered targets.

The transition from the world of rights to the world of politics entails negotiations and elections, the mobilization of conflicting interests, agreements, and the administration of scarce resources. In sum, it means a shift from the ideal world to the world of scarcity. To the extent that new forms of collective action are grounded either in human rights discourse or in religious fundamentalisminvolving, in both cases, demands of a moral nature, meaning that they are absolute and non-negotiable - they hamper the crystallization of political-party projects, thereby driving a wedge between morals and politics, between rights and interests.

The process of creating new rights, and new subjects of rights, has shifted demands and expectations concerning wealth distribution and social recognition toward the legal system and the Judiciary. These new rights operate, at times, as rights "by default"; that is to say, rather than actually being cumulative, they are used by social actors to fill the gaps created by the deficiencies-and sometimes simply the suppression—of the "old" social rights.

The judicialization of social conflict and the new social actors, then, has limited effectiveness as a vehicle for reducing social inequity inasmuch as it creates niches for the representation of fragmented interests, in the absence of a vision of society as a whole. This weakens political parties inasmuch as they are supplanted by new actors, particularly NGOs, whose demands generally are more symbolic than 
practical and who take over the political party function of representing moral discourse and designing new social utopias.

The growing pressures and expectations shifted to the Judiciary exposed its limited ability to solve problems requiring executive or administrative responses, which, in a democratic society, fall outside of their purview and the scope of their functions. As these limitations are revealed, they have a destabilizing effect on the Judiciary, which tends to splinter based on its identification with the various social groups whose interests are riding on its decisions. Meanwhile, despite their growing ability to mobilize public opinion, NGOs are extremely limited as political pressure mechanisms since their legitimacy is undermined by their lack of a clearly-defined social mandate or constituency.

In view of the status accorded human rights as the common ideology underlying contemporary political discourses, the progressive conversion of the Judiciary into an arbiter of social conflicts, and the role of a legal regime regulating rights that transcends national borders, it is necessary to reexamine the system of institutions upon which the national State was erected, with its more or less defined separation of powers and conflict resolution mechanisms. In the new context, politics are judicialized, the Judiciary is constitutionalized, and constitutions are crafted around the values espoused by an increasingly trans-national public opinion that is no longer circumscribed by national borders.

As we shall see, the development of the "democratic paradox"-growing egalitarian expectations accompanied by deepening social inequity-has more to do with social transformation, globalization processes, and the growing influence of the North American model of society than with any particular economic policy agenda. This influence, however, was built on elective affinities and accommodations between the social and institutional processes within each national society as well as on international institution-building models. In this context, the United States and, to a lesser extent, Europe, clearly have the capacity to impose institutional models, 
either directly, or indirectly, through international financial institutions and private foundations.

Nonetheless, the mechanisms that propagate inequality must be detected within each national society, since external forces or globalizing trends are absorbed by domestic institutional systems. Even as we contemplate the relevance of the interplay of factors relating to globalization and the implantation of the neoliberal economic model, which varies from case to case, we must not forget that the levels of social inequality in Latin American countries have been remarkably consistent over time. Therefore, globalization should not be used as the rationale for disregarding the institutional dynamics of national societies, which are still the main venue of social interaction, life opportunities, and individual destiny for much of the population.

The legitimacy of public action in contemporary political systems, nationally as well as internationally, is based on human rights discourse. Once this discourse came to represent the normative horizon of current democratic thought, critiques of its underlying premises have been limited, in the modern tradition, to a relativization of the human rights world as one cultural system within other possible systems. We are not, however, interested in pursuing a philosophical discussion here but with the political appropriation of human rights by social organizations and institutions. Therefore, the sociological question raised by human rights discourse does not refer to its potential epistemological limitations or internal contradictions, but rather with how different social actors use this type of discourse and the attendant political repercussions.

From the standpoint of this author's particular field, sociology, Iconsider it pertinent to link two disciplines: sociology and legal studies. My quest for interdisciplinary dialogue is based largely on a concept as central to conventional wisdom as it is to sociology and law: the concept of citizenship. This book, therefore, may be read as an effort to critically reconstruct this concept in order to demonstrate the reasons behind, and consequences of, its association with virtually every contemporary cause-driven movement, to the point of banality. Understanding 
citizenship, its underpinnings and its limitations, as a core mechanism for the selfrepresentation of individuals in modern society should not only contribute to a more rigorous use of this concept in the social sciences-which tend to mirror conventional wisdom-but also should enable us to detect the problematic consequences of extending the notion of "citizenship" to any and all demands for rights, an extension that tramples its specific meaning, in other words, its meaning as the basic rights that ensure democratic life.

I recognize the risks incurred by offering generalizations about Latin America, although we take pains to point out, to the extent possible, the diversity of national circumstances. Since the processes analyzed herein are present in all democratic capitalist societies, Latin America is treated as a laboratory for social theory and not as an intellectually isolated "area studies", where social theory is applied to "case studies".

I would like to point out that the ideas presented here are the fruit of discussions that took place during the seminars I gave together with Jean Michel Blanquer at the Institut des Hautes Études de l'Amérique Latine (IHEAL) and with Daniel Pécaut at the École des Hautes Études en Sciences Sociales during the period I held the Simón Bolivar Chair at IHEAL. I am grateful to them both for their friendship and their intellectual support. Finally I would like to thank Joel Edelstein for helping with his comments to improve the translation and making me aware of ambiguities in the text, sometimes already contained in the original version. 


\section{CHAPTER I - Citizenship and Human Rights}

The study of citizenship in the Latin American context poses a dual difficulty. The first is general in nature and faced by anyone working with this concept, since it contains both an empirical and a normative frame of reference. The empirical reference has to do with citizenship as it is manifested in each historical or social context, while the normative relates to citizenship as an ideal that is usually enshrined in constitutions and expressed in the feelings, expectations, and values, more or less diffuse, of social actors. The second difficulty is that, in the Latin American context, this "bivalence" (often a source of ambivalence and analytical confusion) involves an additional layer of empirical and normative references. When the social sciences in Latin America (as well as political ideologies or conventional wisdom) refer to an ideal of citizenship, it is against a mental backdrop implicitly or explicitly informed by the specific experiences of citizenship in developed countries that transforms that empirical world of experiences into an idealized world.

By adopting as the ideal reference citizenship as it actually exists or existed in Europe or the United States, social analysis enters into a game of mirrors from which it is hard to extricate itself inasmuch as it adds many layers of confusion between the ideal and the real, or the normative and the empirical, by intermingling the ideal with complex and constantly mutating historical realities. Social scientists, then, find themselves in the position of having to explain-based on an idealized and homogenized image of those countries that fails to take into account the diversity of national trajectories - why we lack certain characteristics typical of developed countries. $^{2}$

However, if for the most part, Latin American political models were imported, the "original" models, in turn, were influenced by diverse national experiences and subject to constant mutations. The construction of citizenship,

\footnotetext{
${ }^{2}$ For a more thorough discussion of this issue, see Bernardo Sorj, "Crises e horizontes das ciências sociais na América Latina”.
} 
whether in France, the United States, Japan or Germany, was, and still is, a complex, arduous, and uneven process that cannot be distilled into a static, stylized image based on its representation toward the latter part of the twentieth century. These circumstances clearly preclude a simple comparison between the relative homogeneity of democratic institutions in the central countries (as seen from the periphery) and the difficulties experienced by developing countries. What is more, in addition to the misuse of concrete historical experiences, Latin American social sciences tend to apply the normative theoretical models of citizenship shaped in developed countries, resorting to abstract constructs disconnected from their historical and cultural roots.

The most harmful consequence of characterizing citizenship as it is observed in developed countries as the ideal and desirable world is that it is contrasted with an image of citizenship in Latin American countries as a world of paucity and deceit, an empire of inequality and arbitrariness. This analytical Manichaeism contributed to the development of a two-tiered unrealistic image: that of advanced countries and that of developing countries; instead of pointing out contrasts and complexities, social analysis metamorphoses into censure and demonization. Rather than uncovering the different historical forms and meanings of the social construction of citizenship, the social sciences often mainly reflect the frustration of intellectuals and local middle classes with their own societies. This attitude, while understandable, fuels a secular tendency to demoralize existing democratic institutions; at the same time, the social sciences miss the opportunity to demonstrate that Latin America is a goldmine of social experiences that, upon closer examination, pose theoretical and practical issues that are just as relevant for advanced capitalist countries.

\section{The diverse forms of citizenship}

The concept of citizenship challenges the social sciences to distinguish between its meaning in the conventional wisdom, with its powerful normative component, and a more rigorous notion with empiricalanalytical value. This problem is particularly acute in Latin America where, in recent decades, the concept of citizenship, or 
"access to citizenship" has evolved into "access to the ideal world," and has been used in this sense by most social movements and nongovernmental organizations, as well as by "socially responsible companies," international entities, and public policy makers. As a result, citizenship has become a polysemous concept imbued with essentially normative connotations.

The first step in elucidating the concept of citizenship consists of inserting it into the dynamics of each historically determined society where it acquires specific characteristics. Our interest here is to characterize citizenship in modern societies. In the modern world, citizenship has always been associated with different types of political systems (for example, liberal, fascist, communist, or fundamentalist theocracies). Our analysis will focus only on citizenship in capitalist countries with liberal democracies. And even in those countries, citizenship presents enormous historical and national diversity, so we must also identify its varied institutional mechanisms and forms in contemporary Latin America.

Here we risk stumbling into a form of relativism in which there could be an infinite number of "citizenships." We must therefore discern, through theoretical and comparative analysis, the essential common components for the existence of a liberaldemocratic citizenship, without which the possibility of citizenship in a democratic capitalist society would be unimaginable.

Citizenship in the modern world is, in the first instance, a mechanism for inclusion/exclusion, a way of defining who is an integral part of a national community. It is, therefore, the expression of a collective construct that organizes relationships between the social subjects created in the process of determining who is, and who is not, a full-fledged member of a politically organized society. This ascriptive feature of citizenship is generally ignored inasmuch as it is defined in terms of individual rights. Citizenship is an institution that confers a specific entitlement; it is a ticket to enter the national community that provides access to a series of rights - a ticket that is obtained, of course, based on a system of criteria (for example, place of birth and nationality of direct ancestors) set forth by the 
established authority. Access to citizenship, then, is the filter used to determine who may participate in each nation's system of political and social rights.

Secondly, citizenship presupposes the existence of a cultural and social community associated with a national identity. In other words, citizenship is associated with the expectation of shared language(s), codes of behaviour, tastes and customs (with all of their regional or social variations), and the sense of a common destiny. The classic expression of this sense of common destiny was military service based on universal conscription, linked to the willingness to die for one's country. This innovation emerged with the French Revolution and, beginning with Napoleon Bonaparte - father of the imperialist patriotic wars-made it possible to convert the entire citizenry into cannon fodder for military exploits that would culminate in two world wars.

While it is true that the national dimension of citizenship, as we will see, is subject to growing crisis (one has only to cite the emergence of professional armies and the end of mandatory military service as a sign of the times), that create tensions between citizens and the national community, citizenship as an identity built on an historical-cultural community remains a constant in modern times. ${ }^{3}$

Alongside the family, citizenship is the initial point of affiliation for modern men and women. It establishes the basic coordinates of their identity, origin, and place in the world. For a long time, nationality was viewed as a natural fact, and the type of debate introduced by egalitarian ideologies centered on the unequal distribution of family wealth among those born within each national society. In today's globalized world, the perception of the origin of social inequality increasingly is associated with the arbitrary fate of having been born in one country as opposed to another, rather than with uneven access to social wealth determined by the equally arbitrary fate of having been born into a particular family. Based on this new perception, then, citizenship is an unequally distributed asset and the main source of stratification of the opportunities available to the inhabitants of the contemporary globalizing world.

\footnotetext{
${ }^{3}$ See Dominique Schnapper, La communauté des citoyens.
} 
Contemporary citizenship is always twofold: it refers to individuals as part of a nation or individuals as part of a people. . The citizen identifies the individual as part of a community, in which the citizen recognizes him or herself, and is recognized, as an equal. Between the two poles of individual-community, there is a constant tension - since from the time of the French Revolution ${ }^{4}$ - that plays out in the conflict between those who place emphasis on individual freedom and those who uphold the value of equality and/or fraternity.

The components of the individual-nation duple are not separate and distinct. The individual is simultaneously a unique being-inclined to optimize personal interests using his or her instrumental rationality—and part of a sociocultural community endowed with a system of values and a sense of belonging where the individual finds the motivations and social context in which to apply his or her reflexive capacity and social insertion strategies. That is to say that autonomy and liberty are meaningful and can only exist in the context of a community substratum of shared values. If it is true that the individual presupposes the existence of community, then it is also true that the modern community in democratic societies can only exist as an expression of the will of free individuals.

The formation of the "national community" was a multilayered process in which languages, dialects, and transnational loyalties were suppressed, altered, or replaced by a homogeneous culture stressing, above all, "loyalty to the fatherland" Institutions associated with the Old Regime took on new meaning and were integrated into the framework of the new society. One of the most eloquent examples of the latter was the redefinition of the institution of marriage and the role of women. The principles of liberalism did not lend themselves readily to a life contract and the subordination of women. The French Revolution and the Napoleonic Code solved the problem by transforming the family and women into pillars of the national community responsible for producing and raising future citizen-soldiers and citizenmothers. ${ }^{5}$ The subordination of women to the needs of the national community is

\footnotetext{
${ }^{4}$ See, for example, Ladan Boroumand, La Guerre des principes.

${ }^{5}$ See Ignacio Terradas, "Familia y ciudadanía en la Revolución Francesa".
} 
symbolized by Marianne, where the female figure became the most important visual image of the nation. It was only through protracted social struggle that women were able to establish themselves as individuals and dissociate themselves from their role as reproductive agents at the service of the nation.

Citizenship is, then, a slippery concept, a sort of "hinge" situated at the intersection of the individual and the community. It is the mechanism by which individuals can lay claim to their individual liberty and simultaneously assert their belonging to the group. Belonging is an acknowledgment that one's individuality is contingent upon the course taken by the the national society, since the group destiny will affect one's personal destiny, and that citizenship cannot be passive or selfcentered, even when confined to the defense of individual freedom. In democratic societies, the public sphere is the political space where the individual will is trans lated into the collective will, where individuals negotiate their personal interests and their versions of the common good.

The individual-nation duple also refers us to the various traditions of building citizenship and, specifically to two major currents: the U.S. Revolution and the French Revolution. While the first was essentially political in nature-its main objective was to protect citizens from the State so that each individual could enjoy his or her freedom to the fullest extent-, the second sought to reconfigure the social order by assigning the State an active role in the realization of society's shared values. ${ }^{6}$ The French Revolution invokes the republican tradition; it is premised on political participation and assigns the State an active role as the expression of the will of the people and guarantor of the values of solidarity and fraternity, which are implemented through social institutions (particularly the school system). These two visions subsequently were joined by republican-socialism whose values of equality were promoted and upheld mainly by the working class.

These two interwoven principles — that of community and that of the individual-are the two pillars of modern citizenship: the sovereignty of the people and equality of

\footnotetext{
${ }^{6}$ An interesting comparative analysis of the 1776 and 1789 revolutions contrasting the views of Hannah Arendt and Habermas can be found in Antonio Negri, O poder constituinte, Ch. 1, pp. $24-41$.
} 
citizens before the law. The principle of sovereignty represented a radical departure from the traditional notion of temporal power as the expression of divine will or some other transcendental source. ${ }^{7}$ In the modern vision, the authorities and the law are seen as emanating from society itself and their agents exercise authority as delegated by the people. The principle of the individual meant that the new sovereign entity, the people, would be made up of individuals equal before the law and endowed with the same package of rights and duties.

Citizenship is an historical reality and as such, evolved over time as it was absorbed by societies with diverse traditions and social structures. Despite the wide range of concrete experiences, or perhaps because of them, theoretical models were developed in an effort to synthesize the evolution of citizenship. The most widely disseminated of these, T. H. Marshall's model, ${ }^{8}$ continues to be a benchmark in much of the specialized bibliography_particularly that of Anglo-Saxon origin-despite the ample criticism it has attracted. For this reason, we will examine it more closely.

According to Marshall, citizenship developed as the ideal of equality spread from the legal sphere into the political and social spheres. Equality before the law fueled the struggle for equality in political participation (universal suffrage) which led, in turn, to progress in the area of social rights. According to Marshall, social citizenship in capitalism is rooted in the contradiction between legal and political systems established to ensure equality among citizens, and an economic system based on unequal access to property. Political rights, and later social rights, offset the disjuncture between the two systems by seeking, not socioeconomic equality among citizens per se, but rather equal opportunity, basic security, and protection of the most vulnerable sectors of society (children, the mentally ill, the sick, the unemployed).

Marshall's model was criticized as an abusive generalization of one particular experience — the British—, as well as for its unilineal evolutionary vision, its naïve optimism, and its historical fatalism (keep in mind that even though alternatives to the liberal/socialdemocratic model, such as Nazism and Communism, were

\footnotetext{
${ }^{7}$ As Marcel Gauchet shows in La religion dans la démocratie: parcours de la laïcité.

${ }^{8}$ See T.H. Marshall, Citizenship and Social Class and Other Essays.
} 
defeated, this was not preordained, as Mann points out ${ }^{9}$ ). Marshall also failed to predict other areas of rights (such as ecological, cultural, and those of sexual minorities), and the crisis of the welfare state two decades after the publication of his famous conference.

Studies on citizenship in Latin America frequently cite Marshall's work to demonstrate that processes associated with the evolution of rights in the region were totally different than such processes in Europe. The problem is that Marshall's stylized model cannot be replicated, in practice, in any European country: not in Mediterranean countries (in Spain, Italy, and Portugal, many "social rights" were implanted by authoritarian regimes), nor in Germany, where social rights were the invention of a political system that had yet to universalize civil rights. Even in the United Kingdom, progress on rights was not a natural endogenous process, but was associated instead with social transformations triggered by its participation in two world wars and with the prestige the Soviet Union conferred upon the Labor Party in the 1944 elections. In the United States, the full civil integration of African Americans postdated the social policies implemented by the Franklin Roosevelt administration.

Therefore, the fact that the Latin American experience does not dovetail with Marshall's model is not an anomaly requiring an explanation as such. Citizenshipbuilding processes are unique, just as the economic structure of capitalism in each country presents its own nuances.

The main theoretical issue that Marshall did not, in fact, address was the complex relationship between different rights. Far from a process of harmonizing various values, from the outset, the history of citizen's rights has featured persistent tensions around the need of harmonizing the wide variety of conflicting demands that are constantly emerging out of society. .

\footnotetext{
${ }^{9}$ Michael Mann, "Ruling Class Strategies and Citizenship". See also, among others, Martin Bulmer and Anthony Ress (orgs.), Citizenship Today; Bryan Turner, "Outline of a Theory of Citizenship".
} 


\section{Citizenship and the antinomies of human rights}

As Bobbio points out, ${ }^{10}$ different categories of rights (legal, political, social) reflect different kinds of relationships between the citizen and the State. While civil rights developed mainly as citizen defense mechanisms against the arbitrary power of the State, political rights are the expression of the integration/participation of citizens in the State and, finally, social rights contain citizens' demands of the State. From the sociological standpoint, the way rights develop reflects the institutionalization of mechanisms to integrate the social groups that capitalism originally condemned to positions of subordination and/or poverty.

Different rights are associated with different values and their implementation, again according to Bobbio, can produce antinomies. For example, the right to property might clash with distributive rights, the right to smoke or take drugs might be at odds with public health policy, and the right to information could conflict with privacy rights, and so forth. It was necessary to find a coherent solution to the antinomic nature of rights in the legal system, particularly in modern societies governed by the Napoleonic Code. In these cases, the State's desire to monopolize the law was associated with the development of a systematized and complete legal regime in which the judge's only function was to apply the law. As we shall see, accompanying the increasing diversification of rights was a parallel increase in the discretionary powers of judges or constitutional courts as the highest authority for legal interpretations and rulings on the hierarchy of priorities associated with the values expressed in legislation.

It should be noted that the antinomic nature of rights is evident in the difficulties associated with the simultaneous application of different values that are considered absolute. This should be distinguished from political antinomies, that is, the way actors perceive the impact of those values in the political arena. . For instance, the passage from civil to political citizenship, and from political to social citizenship, sowed panic among sectors of the dominant classes who feared that universal suffrage or new social rights would mean the end of private property. The

\footnotetext{
${ }^{10}$ Norberto Bobbio, A era dos direitos.
} 
history of liberal capitalism, particularly (but not only) in Latin America, is rife with attempts to limit universal suffrage and coup d'etats that totally disregarded the will expressed at the polls.

Recognition of the antinomic repercussions of applying the values underlying different types of rights is essential to understanding the political, social, and ideological dynamics of modernity; it raises the importance of not confusing rights (as a value system) with law (as a legal system). The latter always will represent a practical, if not precarious, means of harmonizing antinomic values and therefore will reflect an effort to delimit and prioritize the values expressed in "rights" in their generic sense, each one of which is absolute from the ethical standpoint.

Underlying the antinomy of human rights values is a dual entitlement that is at the root of modernity: the full exercise of individual liberty and the equality of all citizens in a national community. The former speaks to individualistic values, while the latter signifies supra-individual values of solidarity. The former presupposes a State that actively ensures the freedom of each individual and the latter a State that ensures the access of the most disadvantaged sectors to minimum conditions of social integration.

Historically, it was the propertied classes that endeavored to confine the model of capitalist modernity to the defense of individual liberties, while the working and poor classes hoisted the banner of equality and social justice. The core dilemma of liberal modernity is how to expand collective interests without diminishing or destroying individual freedoms. Philosophers, political scientists, and ideologues have long sought definitive answers to this dilemma, yet the solution will always be precarious and changing. And although this dilemma eludes a consensus-based, definitive response, history offers a negative lesson: any effort to eliminate one right in favor of another, whether to build an egalitarian society without free individuals or to assert individual freedoms in the absence of solidarity, transforms society into either a prison or a jungle. 
The conflict, usually violent (at least in the perception of social actors), between individual liberty and social equity—or, as Luc Ferry and Alain Renault put it, ${ }^{11}$ between freedoms-rights and entitlements-rights (entitlements vis-à-vis the State), also known as material rights-traverses modern political history and found its classic expression in the clash between liberalism and socialism and communism. Efforts to create models of society navigated, and still navigate, between those who, in the name of individual rights, refuse to accept that the State should ensure greater equality and those who, in the name of equality, are willing to restrict and even eliminate individual freedoms. But, as we shall see, the redefinition of social actors and the types of equality demanded alter the terms of this synthesis.

In classical socialist tradition, and particularly that associated with the work of Karl Marx, critiques of civil and political liberties were articulated in the name of a social reality embodied by the European proletariat of the mid $19^{\text {th }}$ century. According to Marx, equality before the law was a façade that masked the very real inequities in living conditions. The "man" referred to in human rights discourse, according to Marx, is the self-centered individual, isolated and separate from the collective. The communist movement, and part of the socialist movement, never succeeded in divesting themselves completely of the notion that individual rights and the modern legal system were at the service of the dominant classes.

In Latin America, up until the 1970s, the local version of this mindset included the notion that the Judiciary (and, in general, the Legislative Branch) were at the service of the oligarchy and imperialism and that strong governments and the destruction of "bourgeois" liberal institutions were required to carry out reforms that would ensure economic development and wealth distribution policies.

As Claude Lefort showed, ${ }^{12}$ the Marxist perspective is based on a world vision that reduces society to relationships of exploitation and domination. In that universe, there is no room for politics except through a sudden revolutionary explosion, since the prerequisites of political life include freedom of thought,

\footnotetext{
${ }^{11}$ Luc Ferry y Alain Renault, Philosophie Politique.

${ }^{12}$ Claude Lefort, L'invention démocratique, Ch. 1, "Droit de l'homme et politique".
} 
expression, and association, individual autonomy, the existence of a public sphere, and civilized forms of opposition. In synthesis, an autonomous legal sphere is the precondition for ongoing social regeneration, including the defense, expansion, and creation of new rights.

In Latin American countries the experience of the military dictatorships of the 1970s and 1980s and the fall of communism propelled leftist intellectuals in the direction of a human rights-centered ideology. Yet a vast gray area still shrouds the relations hip between human rights and the institutions that are supposed to guarantee them, and it is nourished by extreme social inequality, gross disparities in access to administration of justice, corruption, and the disillusionment afflicting political life. At the same time, an obsolete, anti- liberal Marxism persists, along with a tendency to associate liberal democracy with U.S. hegemony, and a fascination with authoritarian regimes that espouse egalitarian social policies and/or offer a discourse hostile to economic and cultural globalization, even if it entails the suppression of individual liberties, freedom of expression, political and trade union organization, and cultural creation.

If, in the name of equality, some sectors of the "left" were willing to sacrifice individual liberties, some right-wing sectors, fearing the advances made in the demands of working and poor sectors, sought to restrict access to suffrage and trade union organizations.

That said, although the arguments emanating from the left and the right may reflect unilateral visions, both sides raise legitimate theoretical and practical issues: what are civil and political liberties worth absent a minimum level of access to the wealth of civilization and effective opportunities to compete in the labor market? By the same token, social solidarity cannot become the justification for the State to amass enormous discretionary power and expand its sphere of action into areas that impinge on individual liberties.

The growing complexity of the legal system beginning in the early $20^{\text {th }}$ century, including its absorption of new social rights, sparked a liberal reaction to the 
Judiciary's struggle to maintain its particular standing in the political system. As the legal system gradually became a depository for material rights, the Judiciary moved away from upholding society's basic, universal values, to become just one more political actor. From a conservative standpoint, Max Weber previously had lamented this "substantiation" of the Law, a view that was revisited nearly a century later, and from a different angle, by Habermas in his critique of the State's colonization of society. ${ }^{13}$

Now, at the dawn of the $21^{\text {st }}$ century, instead of a Marshall model-in other words, of a series of citizenship styles that are cumulative over time-a very different process is in evidence. It is characterized by the implosion of rights; the transformation of civil and political rights through the incorporation of new social subjects (gender-based, children, sexual minorities), the emergence of new spheres of rights (such as ecological, reproductive, and information) and a mutation (generally a decline) of seemingly consolidated social rights, in particular those related to the workplace.

Marshall's proposed framework, involving the concept of civil and political citizenship completed by social citizenship, made sense in that the latter had to do with a series of rights that could be regarded, in a way, as an extension of the former, since the right to property is a core ele ment of access to civil life. In effect, social rights relating to the workplace constituted a new form of property distribution by means of what Robert Castels described as access to "social ownership.","

Returning, then, to the initial issue of the fundamental mechanisms that serve as prerequisites for the existence of citizenship, at least in the current phase of the crisis of the postwar "socialdemocratic synthesis"15 in which labor rights have been fragmented and increasingly take a back seat to a myriad of new rights, perhaps it is necessary to revisit the distinction between fundamental rights, meaning those that enable the exercise of citizenship, and those rights associated with the demands of specific groups.

\footnotetext{
${ }^{13}$ See Jürgen Habermas, The Theory of Communicative Action.

${ }_{15}^{14}$ See Robert Castel and Claudine Haroche, Proprieté privée, proprieté sociale, proprieté de soi.

${ }^{15}$ See Pierre Rosanvallon, La crise de l'état-providence.
} 
In the context of the proliferation of rights, either conventional wisdom is followed - and each one is defined as a new "dimension" of citizenship and therefore synonymous with "rights"- or they are assigned a precise theoretical and political meaning. Regardless of the legitimacy of any connotation that conventional wisdom might attribute to the notion of citizenship (and an analysis of the different ways in which this term is appropriated and used is a relevant subject for social science research), from the analytical standpoint we can identify two very different sets of rights as they relate to citizenship.

The first cluster is made up of civil and political rights that affect all citizens universally. Inasmuch as they affirm the equality of all individuals, these rights are preconditions for democratic life and for the struggle for specific rights. The second cluster comprises demands by specific social groups, usually entitlements-rights, which often serve as prerequisites for the effective enjoyment of civil and political rights.

This distinction enables us to examine the systemic tension between the basic mechanisms that guarantee the existence of citizenship in liberal capitalist societies and the new rights that emerge and are legitimized in the name of fundamental rights. It likewise facilitates an examination of the nature of the changes that occur as the legal system absorbs new rights. In democratic capitalist societies, confining citizenship to civil and political rights does not mean rejecting the social and moral relevance of other rights or forgetting that civil and political rights are constantly changing. The distinction between rights associated with citizenship and specific rights serves the theoretical purpose of creating a frame of reference for analyzing the impact of the demand for new rights - usually related to specific social groupson the underlying conditions for preserving the legal-political system in modern societies.

This perspective allows us to tackle a central issue in contemporary societies: the transition from "rights" to law. The latter cannot be regarded simply as a translation of "real" social demands into formal legal language. Two types of action 
are required if this transition is to be effective. The first, which will be discussed later, refers to the political and institutional development of new rights in such a way that they can be assimilated effectively by the legal system and by government institutions, after having been formulated by the political party system and included on a political agenda. The second area of action is to integrate the new rights into the language and specific categories of the law. As we shall see later in the example concerning labor law, this means recognizing that legal categories are not merely a reflection of social realities, but are rooted in another sort of abstraction and discourse, in particular the abstract category of the individual as a legal subject upon which modern interactions are constructed. 


\section{CHAPTER II - From Labor Rights to Minority Rights}

The freedom-rights and entitlement-rights dichotomy cuts across modern political history. For two centuries in Europe and one century in Latin America, the integration of the worker-or of the working world in general-into the modern legal and political systems was the center of gravity of social conflict over entitlements-rights. This integration was associated with the struggles of trade unions, social movements, and political parties to gain access for all citizens to a minimum package of goods; mostly this was accomplished through the mobilization of national, and even nationalistic, symbols of inclusion although occasionally it occurred within a framework of internationalist notions. As we shall see, social groups have changed and other types of demands and symbols are used today, far removed from the references to the national State and from the socialist utopia centered on the workers' movement.

Our focus then, is on the decline of that worker-employer conflict, in its dominant form, during the $19^{\text {th }}$ and $20^{\text {th }}$ centuries. Before moving on to contemporary processes, it is important to point out how some of the trends that seem unprecedented to us today, were a response to inherited problems-and therefore are a continuation of them-or constitute trends that were woven, in part, during the struggle to broaden social rights linked to the workplace.

\section{The transition from labor contracts to social rights}

Social justice values predate modern discourse developed around the concept of subjective rights, in other words, around the notion that each individual is a rightsbearing subject, in a world in which the legal system is completely separate from religious institutions and premised on a rational agreement between members of a 
community. ${ }^{16}$ In contrast to modern individual rights, claims of entitlement to "social rights" occur throughout the history of humankind. In the New Testament of the Bible there are countless examples of guidance referring to the welfare of the poor. And while the concern for the "social" does not presuppose individual rights, the opposite is equally true, as can be observed even today. The fact that individual liberties do not necessarily go hand in hand with social justice is clearly illustrated by Asian societies such as Singapore, Taiwan, or Korea which experienced decades of authoritarian regimes and yet exhibit significantly less social inequity than contemporary liberal Anglo-Saxon societies or even continental Europe.

The establishment of social justice mechanisms in a world of individuals, that is to say, a world in which individuals are the only legitimate subject of rights and relate to their neighbors based on freely established contracts, was an historically formidable and highly complex task. It was in confronting the challenge of maintaining the tension between the values of individual liberty and those of social solidarity-without resorting to the authoritarian responses of communism and fascism - that it became possible to humanize capitalism and build the welfare state.

As Alain Supiot demonstrates, ${ }^{17}$ modern law had to address the contradiction implicit in a labor contract in which free and equal individuals consent to relationships of subordination and obedience. It is a contradiction that raises the question of what work really is: an attribute of the individual or a thing? And that which is being subordinated, is it the work or the worker? In order to address this contradiction, it was necessary to establish and legitimize a new area of law: labor law.

Supiot demonstrates how legal remedies to develop labor laws varied according to national traditions. For example, in the Anglo-Saxon common law tradition, with its emphasis on procedural issues and contextual solutions, labor law developed based on distinct scenarios and the definition of different types of "services" provided. In contrast, the French tradition, with its Roman roots, sought

\footnotetext{
${ }^{16}$ See Marcel Gauchet, La religion dans la démocratie.

${ }^{17}$ Alain Supiot, Critique du droit du travail.
} 
inclusive solutions based on an abstract definition of work and a clear distinction between the individual and the thing. Here the emphasis is on the individual freedom of the parties involved, including the freedom to negotiate one's labor, which represents a radical departure from the medieval tradition. Finally, Germanic law, rooted in the premodern tradition of recognizing labor contracts as personal bonds and obligations ensuring mutual protection, acknowledges the community as an entity distinct from the individual and the State. While the individual-centered vision has trouble regarding the labor contract as anything beyond a relationship between free individuals, the community-centered approach confers on the worker a statutory status as a member of a community of workers, in which the individual labor contract occupies a subordinate position. Hence, the focus of the individual contractual relationship is shifted towards the company, towards a community that joins employees and employers.

The history of labor law, and in particular the individualistic tradition propagated in Europe by the Napoleonic Code, is the history of the process of recognizing the uniqueness of the labor code and the need for specific regulations limiting the arbitrary nature of the contract by taking into account that, although it is a contract between free individuals, what is at stake is not only the work, but also the worker. In other words, the "thing," work, cannot be distinguished from the "individual," the worker. The labor contract, then must take into account not only the object itself - the provision of a service in exchange for remuneration-but also the provider of that service. As we are only too aware, this history is intimately linked to the struggles of social movements, trade unions, and socialist political parties.

This conflict involved the tension between the central role assigned to the individual as a basic category of modern law and the incorporation of categories of social groups conferring a status ("worker"), which classic liberalism sought to toss into the trash bin of history. The recognition of collective categories transformed the worker into a legal category thereby paving the way, first, for the legalization of trade unions, heretofore regarded as a monopoly that impeded free individual 
negotiation, and then for the conformation of various collective workers' organizations for the collective bargaining of salaries and working conditions.

This transformation altered the notion of patrimony-an individual's indivisible set of assets and obligations-heretofore viewed as merely an extension of the individual. How to define work? As an object, part of an individual's patrimony and therefore a commodity to be negotiated at the discretion of each person—potentially to the extreme of allowing a slave contract—or as a category giving rise to the intrinsic rights of the individual? As Supiot points out, "the history of labor law was the history of the progressive discovery of the personal dimension of that asset that brought to the fore, not work as an asset, but rather the worker as a subject of rights." ${ }^{\prime 18}$ Underlying labor law is a revolutionary idea - one that would later lead to the establishment of consumer protection laws-that asserts that a contract is only valid if it is made between two equal parties negotiating in conditions of equality.

The integration of these rights, and the recognition of new actors such as trade unions, divided the "worker" persona into the subject and the object of the labor contract. This meant acknowledging that the process of exchanging goods (in the case of the labor contract) entails values unrelated to patrimony, in particular the substratum of the body of the employee. ${ }^{19}$ This process took place without eliminating the juridical personality of the individual as the basis for social regulation.

This legal revolution profoundly transformed capitalism (just as Marx theorized) based on the assumption that a labor contract can be reduced to a purely commercial exchange. ${ }^{20}$ In capitalist societies, however, the labor contract came to be mediated by a social regulatory system that created the uniform conditions and boundaries within which such contracts would be valid, thereby defining the parameters of a commercial contract between two free parties. With the advent of labor laws, the social relations surrounding production were mediated by the

\footnotetext{
${ }^{18}$ Ibid, p.44

${ }^{19}$ See Ibid, p.66.

${ }^{20}$ See Karl Marx, $O$ capital.
} 
political-legal system, while the interests and prospects of salaried workers were integrated into the workings of the democratic system.

In this way, it was recognized that work cannot be dissociated from the worker or, more explicitly, that all work involves a worker (which in turn implies recognition of his or her "physicality," as in, whether that person is a child or adult, man or woman, sick, pregnant, etc.). Labor legislation, then, was concerned primarily with the worker's body, in other words, protecting workers from physical destruction by or on the job; (the "medicalization" of the worker's body initially was associated with work hours - and sleep-as well as occupational accidents which had reached epidemic proportions in $19^{\text {th }}$ century Europe).

Political regulation and labor legislation partially addressed the problem by assigning the employer responsibility for working conditions, essentially through a universal "social security" mechanism. This mechanism, which was later extended to retirement and to the unemployed, was the result, as François Ewald demonstrated, ${ }^{21}$ of the use of statistical know-how, and in particular, the application of business methods to insurance, to solve social problems. In this way, it was possible to socialize the costs of occupational accidents and, subsequently, of old age and unemployment benefits. The right to work, as we have seen, complicated the notion of the contract, although as Ewald pointed out, it also shifted radically the notion of liability. According to the Napoleonic civil code, liability originally was associated with the idea of "fault" and individual responsibility. Conversely, the labor code treats an accident as an "objective" liability rather than the individual responsibility of the worker, and may even hold the employer liable, inasmuch as it recognizes that the worker has forfeited his or her liberty during the employment process.

The affirmation of a legal identity goes hand in hand with affirming the identity of the worker as a specific social group, in other words, with the invention of the modern category of worker. But the opposite is also true: the weakening of identity is accompanied by a transformation of rights. While the right to work created a legal construct of work, it also allowed for professional distinctions which

\footnotetext{
${ }^{21}$ François Ewald, Histoire de l'état providence.
} 
in turn, would reinforce different employer and employee strategies aimed at creating divisions within the category or obtaining differential advantages for each group. In this way, manual laborers and employees, public and private sector officials, unhealthy working conditions and maternity issues, to give just a few examples, began to be associated with differences in rights; this fragmented the workplace and reinforced the corporativism of professional categories. Legislation subsequently incorporated categories of salaried workers into the upper echelons of the company hierarchy, and in recent decades, based on new management styles and employment flexibilization, a broad spectrum of unstable jobs and self-employment was regulated.

Labor law spawned a movement that ultimately led to a new perception of social rights. There was a recognition that, above and beyond specific work-related rights was a human being, or more specifically, a fellow citizen, who had the right to fulfill his/her basic needs, regardless of employment status-including those who for whatever reason (for example, illness or age) were unable to earn a basic living wage. Because of this, rights that had originated in the workplace (including minimum income, retirement, and medical services) ultimately were extended to all citizens, thereby creating the social welfare state.

The creation of a common threshold of rights to security and welfare reinforced trends toward the fragmentation of workers' rights based on specific categories and subcategories. Given the existence of a universal social safety net, employers sought maximum flexibility and individualization of labor contracts and wage negotiations, thereby recovering some of the terrain lost to expanded trade union power.

In this new context, while the most highly skilled workers pursue increasingly individualized strategies, other groups - civil servants in particular- defend their corporate rights and unskilled workers forfeit their bargaining capacity, dignity, and social recognition. This recreated the impression that work is a commodity devoid of subjective qualities; as a result, trade unions and collective bargaining have been weakened and identities associated to the workplace have begun to be dismantled. 
Labor law-and herein lies its significance-revolutionized the basic categories of the legal sphere, as called for by liberal democracy, ${ }^{22}$ opening the floodgates to a subsequent explosion of rights.

In the first place, labor law redefined the distinction between inequality and hierarchy. Although hierarchy-referring to different positions in the chain of command-is certainly permitted, and this includes the recognition of a vast gray area in the labor contract to be filled circumstantially-it cannot confer the power to authorize unequal treatment; put another way, the law will not allow discrimination among workers pursuant to criteria external to the workplace. Thus, the labor contract establishes a hierarchy among equals, including relationships of subordination and limits on the exercise of individual will, yet it prohibits discrimination.

Secondly, labor law established an objective fraternity assumed by the State-a responsibility for the common good outside the private sphere and in particular the family - creating a new collective prototype of citizenship manifested in the form of social rights to a minimum level of security. This fraternal prototype was established as a rational structure based on the recognition of the interdependence of the social system, rather than as a product of the subjective solidarity among individuals. In liberal labor codes participation in trade unions or strikes appears as a right rather than a duty. The liberal vision of trade unions was called into question by the Fascist legal order-which reinstated mandatory collective intermediary entities between the individual and the State - and by the revolutionary socialist tradition, which viewed trade unions as a new form of domination.

Labor law was an effort to integrate the collective, solidary aspects of social life into the legal categories of modernity based on the value of universal individual

\footnotetext{
22 This includes the U.S. legal tradition; for years the Supreme Court tried to block the social legislation introduced by Franklin Roosevelt.
} 
rights. It was a highly complex process, since, as Supiot indicated, ${ }^{23}$ the legal value of equality cannot be confused with the ideology of social egalitarianism, a confusion facilitated, in both cases, by the way in which the notion of equality is used. The introduction of values of material equality-implicitly recognized by labor law and designed to require the regulatory intervention of the State-sought to restore the full effect of legal equality without overlooking the tension between the social and legal dimensions.

The law can err through excess or through timidity: in the former case, through the legalization of particular social categories (such as, for example, the unemployed) leading to the consolidation of that status and the stigmatization of some of the social groups it intended to protect. In the latter instance, it can err by allowing social inequality to deepen to the point of jeopardizing, in practice, the effective functioning of legal categories of equality.

The sense of the collective established by social rights endowed workers with an autonomy they had previously lacked as individuals dealing with the employer, without disregard for their status as individual and autonomous legal persons. The public order would thus establish "individual freedoms to act collectively." 4 Ultimately, labor law and civil law have the same purpose: "to civilize" social relations inside a company, replacing relationships of force-that tended to jeopardize the security of individuals - with relationships of law, so as to transform labor and the company into objects of law.

The importance of the right to work lies in its recognition of the tension between "freedoms-rights" and "entitlements-rights", and between the sociological and legal dimensions of social demands for rights. As Supiot points out, the legal rationale does not seek to reflect or resolve the concrete inequalities found in each society, but rather to provide the legal instruments through which a peaceful, and, to the extent possible, fair, resolution of conflicts can be reached.

\footnotetext{
${ }^{23}$ Supiot, op.cit., p. 135

${ }^{24}$ Ibid, p. 140.
} 
The world of material inequality is tied to different types of power relations among social actors, relations that are in constant flux and upon which the law's capacity to act is limited. To presume that the law can provide a solution to every specific situation of social conflict would destroy the universal rules based on which each subject possesses an autonomous, individual nature. Otherwise, the law would dissolve into society ("represented" by the State in the case of authoritarian societies), giving rise to a reign of the arbitrary and destroying the underpinnings of individual autonomy and fundamental freedoms. As Supiot indicates, "legality presupposes a division between legal rules and other social rules." 25

We must always keep in mind that the legal person is an abstract construct (in practice, concrete people exist, each with their own unique traits). It is a fiction, and is recognized as such, but it also enables all individuals to participate in the rules of law, which attribute "to each individual a space, an identity, that is, the quality of being a legal subject." 26 The promotion of rights should be focused in such a way that they represent, or modify appropriately, existing legal and institutional frameworks. Otherwise there is a risk of stumbling into ideologies that disregard the real prerequisites for implementing new rights.

\section{Social Inequality, Market and State}

The social system established by the welfare state reorganized the bases for social stratification. In advanced countries (and in several developing countries), the State appropriated between one-third and one-half of the Gross Domestic Product and distributed it through public services. When income distribution is used as a measure of standard of living, individual income (which is still used as a criterion for economic stratification) should be taken into account as well as the cost of the public goods and services to which citizens have access (for example, education, health, safety, justice, and subsidized transportation).

\footnotetext{
${ }^{25}$ Ibid. p. 215 .

${ }^{26}$ Ibid. p. 220.
} 
We have, then, a two-tiered stratification: one determined by individual income and the other by the enjoyment of public goods and services. In principle, stratification based on individual income tends to be much more unequal than that produced by inequities in the distribution of public goods and services, which ideally seek not only equity but also to offset market-driven stratifications. Public goods and services are not always effective at compensating for social inequity and in some cases, especially education, particularly benefit the middle classes. In Brazil, for example, the poorest sectors receive, in general, the least benefit from public services and, in some cases the presence of certain services, such as corrupt or abusive police, can actually constitute a hardship for slum dwellers.

Despite a recent trend to delink social policy from market regulatory policies, social rights and public services have always influenced the labor market and the organization of production. To what extent is it possible to develop effective social policies guided by a principle of fair distribution while simultaneously deregulating the labor market in the direction of "contractualism?" While one potential factor underlying the trade unions' growing incapacity to uphold and generate social rights has to do with the liberalization of social policies hitherto associated with the corporate interests of groups of salaried workers with more bargaining power, it is doubtful whether, absent social pressure, the State will be guided by "ethical" policies of expanding public services to achieve equality.

In the $20^{\text {th }}$ century, at least in developed countries, interpersonal solidarity was replaced in large part (although not totally, since the family, friendship, and philanthropy continue to play a key role) by legally regulated social policies. This shift in responsibility signaled a change in the liberal ideal which, while recognizing the importance of solidarity, regarded it as the moral responsibility of members of "civil society" and therefore foreign to the task of governing.

Labor law was rooted in workers' struggles and in government and academic research on the causes of the poverty generated by the new industrialized world that pointed to the need for government intervention. And this altered the very nature of social inequity inasmuch as the latter could no longer be attributed to a divine plan or 
explained as the product of the natural order of things. Poverty eventually was diagnosed as a systemic dysfunction that could be corrected by social engineering (or revolution).

The main policy for addressing social issues was mandatory social security. As we have mentioned, applied statistical risk control technology constitutes the basis for modern social security. The application of technologies for universal, mandatory social security involved two formulas that were applied differently in each country, but were always based on a combination of employee and employer contributions and/or direct taxation.

Over an extended period - from the end of the First World War to the Cold War-a new sphere of government action was consolidated: the social sphere. In advanced countries, the capitalist State became a welfare state and created what Robert Castels termed "social ownership," 27 a series of collective assets considered to be a functional substitute for individual ownership and designed to ensure individuals access to the materal supports (education, health, social secuity) they needed to participate in the labor market and in modern consumption . Rooted in the desire to diffuse class conflict and instill patriotic sentiment in the lower classes, the social welfare state was a social integration project in function of the National State.

The welfare state entered into crisis in the 1970s, although it is important to point out that to this day it continues to be the basis for social integration in advanced capitalist societies. The situation initially was diagnosed as a fiscal crisis due to demographic changes (longer life spans and reduced birth rates, with the attendant modification of the age pyramid so that the system in which the younger generation covered the costs of the older generation was rendered unviable), spiraling public health costs, and rising unemployment.

The crisis of the welfare state is the product of a protracted process in which the "social rights" created around the figure of the worker were generalized and largely delinked from the mandatory social security system that served as their

\footnotetext{
${ }^{27}$ Robert Castels and Claudine Haroche, Proprieté privée, proprieté sociale e proprieté se so. .
} 
funding source. As new sectors joined the welfare state, the costs were transferred to "contributing" groups, i.e. workers and employers, or to the State, bankrolled by taxation or inflationary policies. This new context set the stage for the so-called neoliberal policies, supported by broad social sectors who felt harmed by policies to fund the growing costs of maintaining the system or by inflation. ${ }^{28}$

An enormous amount of literature began to point out that a significant portion of the resources that should be allocated to the neediest sectors remained in the middle classes and that social policies, far from serving as a tool for integration, were reinforcing the stigmatization and proliferation of excluded groups. The welfare state, therefore, was eroding on two fronts: from the top, due to public administration problems, and at its base, due to the middle classes' growing rejection of ideologies espousing social solidarity. Even left-leaning intellectuals began to view increasing government control as an unwarranted, authoritarian intrusion into private life. $^{29}$

Budget administration initiatives to reduce the fiscal deficit in the 1970s, or to comply with the requirements for competitive insertion into the international market in the 1980s, included a series of government reforms, privatization initiatives, and reforms to social legislation. At the same time, a vast amount of literature was being produced on governability and good governance, indicating the need to develop appropriate instruments to ensure transparency and to measure and evaluate the efficienc y of public resource allocation. Despite the reform of the welfare state-still in progress in Europe and in most Latin American countries-, which included the modification or elimination of some labor and social security rights, social spending in capitalist countries has remained steady or even risen, as has the percentage of the public budget in the overall Gross Domestic Product. ${ }^{30}$ Therefore, it is important to keep in mind that the welfare state continues to be the basis for social solidarity and for expectations concerning basic rights in advanced capitalist States. The core issue today, therefore, has to do with the government's ability to offset growing marketgenerated inequities and to limit the noxious effects on the physical and mental

\footnotetext{
${ }^{28}$ Regarding the social impact of inflation in Brazil, see Bernardo Sorj, A nova sociedade brasileira, Ch. 3.

${ }^{29}$ See Pierre Rosanvallon, La nouvelle question sociale.

${ }^{30}$ Although in most countries a growing percentage of public spending financing was transferred from direct taxes (on income) to socially regressive indirect taxes (on consumption).
} 
health of salaried workers from the deregulation of labor relations produced by the contractual counter-revolution

While the dismantling of corporativist structures eliminates certain privileges that clearly are unsustainable in today's climate, it also corrodes the professional ethic associated with activities that require a certain commitment to collective values, such as public services.

And that is not all; above and beyond the administrative and fiscal difficulties, the crisis of the welfare state reflects a deep-rooted social transformation, that calls into question its legitimacy based on the widening gap between the social base of public policies anchored in productive relationships and the egalitarian ideology associated with the working class on one side, and new trends in modern social interactions on the other. As Robert Castels maintains, starting in the mid 1970s there was a "destabilization of collective ownership or even a weakening of the homogeneous categories that comprised the wage-based society." 31

As we have seen, the working world was becoming increasingly fragmented, in part as a result of successful negotiations by different groups of salaried employees. But beginning in the 1970s, a series of internal factors accelerated the internal transformation of the working class. The declining influence of the industrial sector coupled with the growth of the service sector led to a reduction, both relative and absolute, in the number of manual laborers - protagonists of the trade union tradition and egalitarian ideology-within the universe of salaried employees. At the same time, new business administration methods, out-sourcing, job flexibilization, and the shrinking pool of employed manpower, struck at the foundations of trade unions and the occupational strategies associated with expectations of job stability. Finally, the neoliberal ideological wave and the demise of communism further debilitated actors committed to the struggle for a more egalitarian society.

\footnotetext{
${ }^{31}$ Robert Castel, op. cit., p. 108.
} 


\section{From anonymous domination to fragmented rights}

The "crisis of the working class"- and its social utopias—is both a cause and effect of the growing individualization of values and social relationships in modern society. This process has led to what some sociologists consider a new phase of modernity (referred to variously as "post-modernity and "high modernity"). ${ }^{32}$ At its center is the individual, bereft of transcendental beliefs or tradition and condemned to constant reflexive action, in others words to a subjective world under constant construction and reconstruction.

The contemporary individual can be seen as lacking a rigid system of collective or ideological affinities and splintered into myriad, mutant networks and reference groups. Unlike the previous modern period, in which a relatively solid values system was still in effect through institutions such as marriage, career, education, political party, and ideology, and offered, at least in broad strokes, a secular sense of life (centered around values such as work, country, progress, history, and socialism), the modern individual has evolved into a self-centered universe populated by black holes and disjointed galaxies and enveloped in a sense of intense uncertainty about his or her future and place in the world.

The current de-institutionalization of the individual, whether man, woman, or child, also has weakened the mechanisms and ties that connect the individual to society and to a cultural system. ${ }^{33}$ The values upon which school, the workplace, and the State were built are clearly in retreat, if not in a state of collapse. New identities are built around financial success and consumption associated with increasingly customized lifestyles. $^{34}$

\footnotetext{
${ }^{32}$ See, among others, Anthony Giddens and Scott Lash, Reflexive Modernization.

${ }^{33}$ See Danilo Martuccelli, Dominations ordinaires.

${ }^{34}$ On the sociology of consumption see, among others, Daniel Miller (ed.), Acknowledging Consumption; Yiannis Gabriel and Tim Lang, The Unmanageable Consumer; Don Slater, Consumer, Culture \& Postmodernism; Pekka Sulkunen, John Holmwood, Hilary Radner, and Gerhard Schulze (eds.), Constructing the New Consumer Society; Jean Baudrillard, Le système des objets; Mary Douglas and Baron Isherwood, The World of Goods; Arjun Appadurai, The Social Life of Things; and Zygmunt Bauman, Life in Fragments: Intimations of Postmodernity; El malestar de la posmodernidad.
} 
Periods of historical transformation create a "dislocation" between the subjectivity of the formative years and the values and demands of the new times, between individuals and society. This dislocation is experienced as a personal crisis and frequently is a source of resentment, frustration, anxiety, and depression. Beginning at a certain age, it is increasingly difficult to "identify oneself" with the "outside world," and this produces a profound existential crisis and disillusionment with life. This situation, while common to all historical transformations, has taken on a chronic and intermittent character in contemporary capitalist society.

Living simultaneously in the physical space where he is situated and in the global space to which he is connected, living with an "in the moment" mentality that obliterates any sense of history, and with no one but himself to blame for his suffering, the reflexive individual discovers that his subjective experience represents not freedom but a source of anxiety that requires the constant application of self-help methods, if not chemicals, to keep up the motivation necessary to continue to be selfmanaging and to endure the constant change and uncertainty of today's world.

This individual is condemned to experience a constant sense of detachment from the immediate meaning of the social world; to live in a world that is fluid and in constant flux, one for which he is not "prepared" (thus creating a new niche for "continuing education"). The individual is forced to justify his every action calling upon different potential rationales and values; to negotiate each action in the affective world; to feel fragmented by a myriad of desires with no structuring values to be found. In sum, he is condemned to live, as expressed in the emblematic title of Ehrenberg's book, "the exhaustion of being oneself." 35 The individual no longer suffers the pressure of the super-I and he directs his energies toward ministering to his desires, now openly acknowledged, but largely unattainable. He is condemned to coexist with his many selves and myriad opportunities to rewrite his life story, transforming each interaction into a negotiation with himself or others, producing a culture in which subjective dramas replace public dramas or, to paraphrase the title of another book, producing a narcissistic culture of the "minimal self,"36 revolving

\footnotetext{
${ }^{35}$ Alain Ehrenberg, La fatigue d'être soi.

${ }^{36}$ Christopher Lasch, The Minimal Self.
} 
around private aspirations and the ongoing — and never-ending-construction of a self-image. ${ }^{37}$

Responsible for his own destiny_-given that he is free to reinvent his life story at any time - the individual is also responsible for his failures and problems: for not having tried hard enough to get a good job, for not having eaten well enough and ending up with health problems, for not having exercised enough and having aged as a result. The contemporary individual still feels oppressed and dominated, but it is an anonymous domination, with no exact name or address. While in the workers' struggles of yesteryear, the enemy had a distinct face (the boss) and the roots of domination were clearly identified (capitalism), the reflexive individual cannot quite figure out who to blame for his ills; this leads to the increasingly prevalent syndrome of depression and a sense of failure, as the person considers himself solely responsible for his misfortunes.

Paradoxically, the new modernity is producing a resigned individual—-too busy taking care of his problems to pay attention to collective issues-and at the same time, a more egalitarian individual since, with the breakdown of the old boundaries and subcultures that divided people (such as social status, social class, nationality, and ideology), nothing is left but one's common humanity, the drama of the human condition in which all individuals can see themselves reflected and identified. $^{38}$

From the sociological standpoint, the overemphasis on the individual and on the liberating role of knowledge that pervades modern culture (and was reinforced by psychoanalysis and various self-help therapies) finds its expression in the school of rational choice, and, more recently, in reflexive individualism. The way certain sociological approaches portray the condition of the modern individual-as a reflexive being constantly reinventing his future, or a "risk taker" in Giddens' words-is a questionable and caricatured idealization of contemporary life. The modern individual bears a closer resemblance to another image, also caricatured:

37 See Marcel Gauchet, "Essai de psychologie contemporaine".

${ }^{38}$ George Simmel, in particular, noted the profoundly equalizing effects of world modernization. See Philosophy of Money. 
that of a prisoner in a cell, from whence he periodically imagines new "life narratives" so as to maintain the illusion that he is at the helm of his own life story.

The idealism implicit in the excessive value placed on subjective experience, on the capacity for learning, and on the role of knowledge in self-transformation recently was critiqued by Danilo Martuccelli. ${ }^{39}$ According to this author, the individual is not sustained "internally" but rather by external "supports" that serve to stabilize the subjective experience (from religion to family, from friends to money).

\section{The new individualism and collective identities ${ }^{40}$}

The new individualism, subjectively "vulnerable" and exposed to anonymous domination, continues to seek new ways of belonging and to demand new forms of protection, solidarity, and social recognition. According to some authors, ${ }^{41}$ this constitutes a radicalization of democracy. Nonetheless, it does not seem to us that the analyses of specific social processes warrant such optimism. Instead, like Marcel Gauchet, ${ }^{42}$ we believe that the postmodern individual has enormous difficulty assimilating the public, dimension. In the new social reality, the struggle for equality is replaced by the struggle for difference; individuals no longer try to build a socially inclusive utopia, and inequality is only relevant in relation to one's own group, rather than society as a whole. What is more, the very idea of a socially unifying secular utopia has lost currency as it is presupposes a degree of trust in universal truths and/or values and a destination point in a common future that is no longer sought.

Individualization destroys unconditional affiliations and loyalties to absolute ideologies. Agreements around specific issues no longer lead to all-embracing visions of the most diverse problems of society. Each individual reserves the right to adopt (or change) a position on a particular issue and does not accept that any position can be reduced to a single interpretative framework. Those who adopt

\footnotetext{
${ }^{39}$ Danilo Martuccelli, Grammaires de l'individu.

${ }^{40} \mathrm{I}$ am grateful to Joel Edelstein for his comments and ideas in this chapter.

${ }^{41}$ In particular, Ulrich Beck, What is Globalization?.

${ }^{42}$ Marcel Gauchet, Op. Cit.
} 
frameworks based on an external authority, equipped with predetermined explanations and responses, emigrate toward religious fundamentalism. In it most moderate or light manifestations, the loss of firm reference points, uncertainty and the sense of a lack of transcendental values and meanings have increased demand for "mystical products," ranging from yoga "light" or other Oriental disciplines to the rediscovery of one's own religious tradition.

Individualism and egalitarianism breed growing distrust toward large bureaucracies, whose opacity and impersonal nature clash with values of transparency and the emphasis on individual needs. The main victims of this new social malaise are the government and political parties, although large corporations may also become the target of public distrust.

In the contemporary world, the transition from the individual to the social can be observed through two seemingly contradictory constructs that exemplify the new condition of the modern individual. For some, the main point of reference is human rights discourse which, because of its highly abstract and general nature, offers a platform upon which particular demands can be anchored and transmitted. ${ }^{43}$ There are others who, once the vision of society organized around the State and the political system has been lost, turn to religion in search of the material to build collective identities, eschewing the uncertainty of everyday society and history.

The new universe of collective identities is no longer based on the socioeconomic ties and historical processes that have become fragile and are in constant flux. These identities seek certainties that will shelter them from social transformations and from individualism itself; they develop through either short-term identification with affinity groups associated with specific issues (neighborhood life, the school), or-and this is truly a new phenomenon-around entities that are (experienced as) natural or transcendental. ${ }^{44}$ Hence, gender, sexual preference, physical characteristics, ethnic group, religion, regionalism, and nature are some of

\footnotetext{
${ }^{43}$ Regarding the role of human rights discourse see Marcel Ga uchet, "Quand les droits de l'homme deviennent une politique"

${ }^{44}$ Modern Nazism and racism were precursors to this way of constructing identity..
} 
the values upon which the new collective actors currently are building their identities. $^{45}$

The new identities operate as filters that delimit the relativizing effects and uncertainties of reflexive individualism; they offer a menu of what is true and false, as well as the potential to identify an external enemy upon which to unload at least some of the responsibility for personal destiny. But these identities are not immune to the influence of contemporary individualism; particularly for the elites among these new social actors, they also represent individual negotiating strategies to obtain positions of power in the political system and resources to ensure upward mobility.

Despite the differences observed among the new identities, they share at least some of the following traits, which distinguish them profoundly from the working world and, in a way, place them in conflict with the latter's claims and demands.

1) Groups that portray themselves as victims of the system, or descendents of victims, for which they must be compensated, although those responsible for the suffering (i.e., slavery, persecution, expulsion from their lands) are hard to identify in the present. ${ }^{46}$

2) Groups do not seek similarity. They assert their differences or uniqueness, are anti-universalists or see universalism as a means of domination. This critique is situated in a complex relationship with human rights discourse, which is redefined as the acknowledgment of the right to be different, a right that amplifies the internal antinomies of human rights and legal systems organized around national cultural communities.

\footnotetext{
45 Michael J. Piore draws attention to the fact that in North American society, with its individualism and its difficulties to live with ambiguities, it is harder to create collective identities except through innate or natural traits (race, gender, physical features, etc.). Piore's analysis, which does not include religion or ecology, is applied today, with he necessary adaptations, to all modern societies. See Beyond Individualism.

46 In this regard, Michael Walzer comments: "“'In multicultural politics it is an advantage to be injured. Every injury, every act of discrimination or disrespect, every heedless, invidious, or malicious word is a kind of political entitlement, if not reparation then at least recognition." P. 89 " Cf. "Multiculturalism and the Politics of Interest".
} 
3) Since the new collective identities are built upon the foundations of "transcendental," permanent qualities, they often seek permanent discrimination, rather than a leveling of the playing field. Parallel to affirmative action policies seeking equal opportunity, the elites of new identity groups advocate positive discrimination policies to consolidate and strengthen particular identities and subcultures.

4) The new collective identities stress the symbolic aspects of domination and oppression, even when advocating financial compensation. They are not organized within the economic or productive context, and therefore lack objective parameters to define "their fair share" in the economic world. ${ }^{47}$

5) Their social make-up cuts across class lines, although in practice these identities may be primarily composed mainly of members of a given socioeconomic group.

6) The new identities are defined outside of the classic right/left parameters and cut across party lines.

As we stated at the beginning of this book, modern citizenship simultaneously incorporated the notion of free and equal individuals and the idea of national community. The growing symbolic fragmentation-caused by the invasion of the public sphere by matters previously associated with "private life" and by the importance placed on ethnic and/or religious cultures that regard their particular loyalties and values as priority and nonnegotiable-jeopardizes the republican notion of public space and the common good.

\footnotetext{
47 According to Michael J. Piore, “.... and because the groupings are defined independently of the economic structure there is no straightforward way for them or their members to comprehend how economic resources constrain the satisfaction of their demands." Piore, Op. Cit. pag. 22.
} 
While these dynamics have sparked an ideological, intellectual, and political reaction, particularly in Europe, in defense of "national" or republican values, from left to right, it is hard to believe that a return to the past is possible. We are living in a very different world than that of the labor and socialist tradition. Instead of a common societal value, i.e. work, we have the assertion of values that are diverse and incommensurate with respect to each other; instead of a radicalization of similarity or equality, we have a radicalization of differences; instead of exploitation, symbolic domination and victimization; instead of universal utopia individual utopias; instead of trust in human activity, the future, and history, uncertainty and distrust of politics.

The building of bridges between private and public life, promoted in particular by feminism, played a significant liberating role in that it introduced into the public debate certain aspects of social life which, in the name of the intimacy of private life, were shielding systems of domination and oppression. But the creation of a continuum between the public and the private eliminates the dynamic tension between the individual, the group, and national society-a tension that fueled the production of utopias whose horizon necessarily had to extend beyond one's own navel. While the separation between public and private life allowed for certain forms of domination that should be criticized and surmounted, it also represents the main bulwark against authoritarian and totalitarian tendencies, whether on the part of the State or society itself, and is critical to the defense of individual liberty.

As groups seeking symbolic recognition, the new identities have the effect of democratizing value systems and cultural life. But once they are dissociated from the struggle against inequality in society as a whole, they have only limited impact on wealth distribution. In the best case scenario, the result is a change in the relative position of identity groups within a system of social wealth distribution that remains largely unaffected. ${ }^{48}$ These identities have the potential to normalize the class structure within the identity group, facilitating the upward mobility of certain layers:

\footnotetext{
${ }^{48}$ Nancy Fraser discusses the limitations of the distributive capacity of new social movements organized around identitary recognition, based on the assumption that a synthesis between the old forms of struggle against economic exploitation is possible. This is an appeal to principle that does not show any evidence of sociological viability. See ¿De la distribución al reconocimiento?. Dilemas de la justicia en la era pos-socialista.
} 
they act as springboards for new elites who use identity politics as a negotiating tool to access better positions in the labor market and public resources, which are distributed unequally within the group.

In this way, emergent social struggles influence the relative position of new collective actors in the market or in the share of public resources allocated to them, while not necessarily having any effect on inequitable wealth distribution in society as a whole. Social inequity today is experienced at many levels and social demands are no longer levied against the owner-employer classes, but rather against public policy and labor market regulations for specific groups. These new identities have a contradictory impact on the democratization of social relations. On the one hand, they reinvigorate democratic life by giving expression to social groups oppressed during the construction of the modern State (women, sexual minorities, ethnic groups). On the other hand, however, not only is their impact on wealth distribution limited, but they also deflect the debate over social equity away from society as a whole, since they generally are associated with the discourse and institutional practices of impermeable interest groups.

In the same way that demands for social rights that disregarded the values of respect for individuality and freedom developed into totalitarianism, the new social demands associated with "identity politics" and multiculturalism could emerge as new forms of postmodern racism, as demonstrated by recent examples from the ideology of the new right in Holland and Denmark and from fundamentalist groups. In the name of differences, identified in this example with national culture, access to citizenship is denied those who do not share the same values or belief system.

The new wave of what are generally referred to as "symbolic" rights, gives rise to a contradiction between democratization and democracy that is not easily resolved. To the extent that the democratization of social rights involves the affirmation of identities that erode the sense of community - in other words the sense of being part of the same world, of shared problems, values and institutions-a core premise of citizenship is, to a certain degree, destroyed: the sense of belonging to a world of "equals." 
Collective identities based on differences greatly reduce the possibility of developing a uniform sociological framework for the study of social inequity, a concept that increasingly refers to the relative position of specific groups within society (women, African Americans, Latinos, immigrants, homosexuals, the list is never-ending). This type of understanding of social inequity dismembers the sense of "society," which is no longer regarded and experienced as a group of equal citizens. Similarly, the matter of distribution comes to be viewed as the "piece of the pie" that "my group" receives. When the demand for rights under the purview of the new collective identities is associated with distributive social demands, there is a risk that the public sphere will become depoliticized and eroded. This is the case because these identities reject politics as the production of an all-embracing utopia and transform the representative system into a process of aggregating the interests of diverse social fragments, an image that is exemplified quite clearly in the United States. $^{49}$

The notion of social inequality becomes multilayered, so that a specific individual may be inserted into it in different positions, depending on the reference group. So, from the standpoint of employment or income, for example, one might be at the top of the pyramid, while one's identification with a particular racial, ethnic, or gender group might entail an inferior position. The multiplicity of inequalities has eroded notions of social class as the basis for creating solid social identities.

The increasingly globalized vision of social stratification radicalizes the perception of multiple social inequalities as they relate to expectations of access to a globalized pattern of consumption definded by the richer countries. While consumption patterns and expectations are increasingly global, national societies continue to be the main locus for the production and distribution of goods.

49 In this regard, Jürgen's Habermas' analysis of public space is premised on individuals devoid of an instrumental relationship. See The Theory of the Communicative Action. On the relation between collective identities and their intersection with law, see Jürgen Habermas, "Struggles for Recognition in the Democratic Constitutional State. 
The proliferation of rights-particularly the expansion of the democratic program to include not only the values of freedom and equality, but also those associated with "alterity" - brings enormous pressure to bear on social systems in which democracy continues to be weak due to historically pervasive social inequalities. To incorporate the "right to differ" in societies that still have a hard time assimilating the "classic" values of equality and liberty poses additional risks of social fragmentation and separatism.

The development of policies that recognize different ethnic identities and that seek the empowerment of ethnic minority groups could either strengthen democracy or accelerate the disintegration of national societies. ${ }^{50}$ The reconstruction of oppressed identities could adopt an approach that recognizes differences and a discourse in which the key to reconstructing identity involves a sense of shared values with the rest of society; conversely, it could be based on a narrative which, in the name of the oppression suffered by the group, ends up fostering a trend toward growing isolation and rupture with society.

It would appear that the second approach has prevailed in several European countries, but it does not represent a serious threat to social cohesion, given that the continent appears to be moving toward some form of federalism, pursuant to which certain government functions already have been transferred to a supranational entity, the European Union. In several cases, separatist tendencies are promoted by affluent regions and their demands express, to some degree, a collective egotism, a "desolidarization" with other, more impoverished regions.

In Latin America, where democratic institutions and social integration mechanisms are much more fragile, the acritical "importation" of the North American experience, historically based on the affirmation of ethnic diversity and accompanied by international assistance for oppressed groups, has promoted, in some cases irresponsibly, support for indigenous groups' demands for legal

\footnotetext{
${ }^{50}$ See Cristian Gros, Políticas de la etnicidad: identidad, estado y modernidad, Bogotá; Oliver Corten and Patricio Nolasco, "Pluralism culturel, pluralism juridique et démocratie: les ambigúites $d u$ discours identitaire zapatiste."
} 
pluralism. As if social inequality could be offset by symbolic mechanisms for legal autonomy which frequently represent a regression toward practices that do not respect human rights and ultimately strengthen male oligarchies within "native" communities.

Todays individual feels increasingly abandoned, uncertain, and unprotected. ${ }^{51}$ Traditionally, protection was guaranteed by systems of domination or of subordination to political-religious contrivances designed to provide symbolic compensation and resignation in the face of suffering and the arbitrariness and uncertainty of earthly existence. In contemporary societies, the protective images and practices were transformed by three interrelated processes: a) the erosion of religious guideposts and the attendant dilution of the absolute values underlying the main modern ideologies, which weakened the sense of ontological security; b) growing individualization, linked to the crisis of traditional systems of domination which ensured security through oppressive mechanisms (such as male-dominated family systems, employer-patronage labor relations) ; and c) technological changes and the globalization of social processes that intensify the sense of impotence and uncertainty with respect to the future.

While the social system has become increasingly complex, the feeling at the individual level is one of increasing enthropy. In the social and existential vacuum created by contemporary modernity, individuals feel condemned to uncertainty and existential defenselessness in spite of the enormous and effective advances in science and technology. Even though people can always weave new ties of solidarity-in friendship, family, or love (the personal utopia and modern chimera through which one hopes to attain absolute certainties, the transcendence that comes from merging identities, the enchantment of the world, and practical protection) - they may try to earn more money, experiment new religions, or seek help from specialists (the vast array of mental health professionals) they still need the State to ensure a modicum of security against a precarious job market, old age, rising health and education costs, the power of giant corporations, urban chaos, and environmental degradation. Even

\footnotetext{
${ }^{51}$ The chasm between the isolated individual and an increasingly powerful state is the subject of an enormous bibliography, beginning with research on the origins of totalitarianism. See in this regard, Erich Fromm's classic work, Escape from Freedom.
} 
violence--a problem over which according to the media the peripheral countries seemed to have almost a monopoly--figures prominently on the political agenda of central countries.

In modern societies people become individualized and society more complex, as individual and social destinies become increasingly intertwined. The basic liberal platform that confined State action to the protection of individual liberties was always a chimera and is not relevant today given the deepening complexities of modern societies. Currency protection and economic control policy, public service supply and regulation, quality control, technical standard-setting, and supporting scientific research are just some of the activities in the modern State's repertoire that contemporary political ideologies do not dispute. What is a matter of debate is what should and should not be protected or regulated and how. Each national society has its own citizen protection systems, shaped by its unique characteristics and history. Yet as we already have pointed out, the crisis of the welfare state has not diminished the State's protagonism in the modern societies of the new millennium.

\section{The crisis of political representation and the role of the Judiciary}

The history of changes in citizenship rights in democratic capitalist societies can be interpreted as the changing relationships between the Legislature, the Judiciary, and the Executive Branch. In simplified terms, the golden age of the Legislative Branch might correspond to the era of access to suffrage, while the expansion of social rights strengthened the Executive Branch. Finally, the Judiciary is playing a central role in the current period.

The shifting positions of the three branches of government is not simply a rearrangement of each branch's influence in the public sphere and of its ability to act as arbiter or even impose its will on the others; instead, it is mostly associated with 
changes in the social representation of politics and with societal transformations that have influenced the role and organization of each branch.

This is evident, in retrospect, in the framework of the welfare state, a period that marked the peak of the Executive Branch, the expansion of the government apparatus and technocracy, and the systematic inclusion of new areas under its aegis (from health to education, from science and technology to infrastructure); all this in function of establishing that branch of government's primacy, not just over the other branches, but also over society from whence its initial impetus had come. As we have seen, these transformations also lad an effect on the Judiciary, which was confronted with the task of integrating new subjects and expanding its jurisdiction so as to bring the law into step with the demands for substantive rights emanating from specific groups.

According to Marcel Gauchet's hypothesis, ${ }^{52}$ the Judiciary's expanding authority in this new phase corresponds to several factors: the desacralization and secularization of the world; the demise of social utopias based on a belief in the meaningfulness of history; the drying up of the welfare state associated with increasing limitations on governmental discretion which, in turn, were a response to the exigencies of international economic insertion; and finally, the development of a new individualism that no longer responded to political ideologies or identification with the public sphere. These changes contributed to the debilitation and declining popularity of party politics and political power in both the Executive and Legislative branches.

These processes shifted the representation of politics toward human rights discourse. Social actors would adopt this language to express their aspirations with the result that politics would no longer be able to find its expression in the language of party politics. While the discourse of party politics requires choices and presumes that there will be different, conflictive stances, as well as negotiations and a certain degree of pragmatism, human rights discourse is inclusive and develops in a world of absolute moral values.

\footnotetext{
${ }^{52}$ See Marcel Gauchet, "Quand les droits de 1'homme deviennent une politique".
} 
The Judiciary's position shifted because its role in society had changed as political representation moved toward a human rights discourse. Parallel to this change was the transformation of the Judiciary itself due to the increasing constitutionalization of the political system coupled with the judicialization of social conflict. The constitutionalization of the political system means that Executive and Legislative action is subject to the jurisdiction of the constitutional courts. The constitutionalization of law reflected a certain confluence between the continental tradition disseminated by the Napoleonic Code and the Anglo-Saxon common law tradition inasmuch as increasingly frequent references to constitutional issues and the growing importance of the Judiciary in social life shifted the judge's traditional role from applying the law to actively interpreting it. The internal changes brought about by the establishment or strengthening of the Judiciary's role as defender of citizenship transformed it into a key political actor.

The judicialization of social conflicts shifts expectations concerning the resolution of demands and social conflicts to the Judiciary as the sole guarantor of peaceful coexistence and the only trustworthy authority. The judicialization of social relations transforms politics and the social actors on the political stage. This is evident in the decline of different forms of participation in party politics and in the fragmentation of social representation.

Ironically, the judicialization of the social sphere weakened the law in two ways: 1) at the institutional level, since all new legislation is viewed in light of its constitutional foundations baed on human rights, and 2) at the level of everyday interpersonal relationships, to the extent that it fosters the growing contractualization of social relationships. This is particularly true of labor relations, although it is also the case with family relationships and the social security, education, and health systems.

The constitutionalization and contractualization of social relations and expectations diminishes the the perception of the law both as a collectively shared convention and a compulsory system switching conflict resolutions to individualized 
agreements and arbitrations and basic expections of justice to a universal system of human rights. In both instances, it erodes the ability of the Executive and Legislative Branches to develop solutions to conflictive situations.

The contractualization of social relations makes it possible to reinstate, in the name of the autonomy of the parties, relations of power and oppression in the workplace, while constitutionalization distances the citizen from the political decisions and commitments made by democratically elected governments. Both trends have positive aspects: the first is an expression of the growing individualization of social relations and the search for personal solutions, while the second is tantamount to the citizen's defense against what is regarded as the arbitrary power of the State. But these trends also entail enormous risks for the consolidation of democratic life, first by forging a social connection tangential to society as if it were a private business. Second, they fail to take into account that political life requires compromise and community members must be willing to distribute the benefits as well as the costs. Both cases are the expression of the contemporary individual's lack of identification with a vision of social relations that requires acquiescing to common standards and, to a certain degree, sacrificing personal interests in favor of the collective interest.

New forms of collective representation together with the loss of faith in party politics and social change ideologies, or their replacement with human rights discourse, weakened the ideological and functional role of the State as the designer of strategies capable of controlling and regulating the process of social change.

The fragmentation of interests, as we have seen, placed the struggle for human rights squarely at the center of public life and strengthened the role of the Judiciary. Behind the back of the Executive and Legislative branches, the judicialization of social conflict and the development of collective identities pose new problems for governance in modern societies. Decades ago, Samuel Huntington described the challenge of governance in developing countries as being one of (mal) adjustment between the pace of expanding social demands to the capacity of the 
political system and the resources made available by the State to process them. ${ }^{53}$ The present-day institutional dynamics cause social demands to be rerouted; they are either directed toward the Judiciary or expressed tangentially to the political system, often behind the State's back. Previously, the danger emanated from an imploding democratic system due to the State's inability to absorb the range of social demands. Today, however, the danger lies in the moral abandonment of the governmental sphere due to the lack of identification with the political system organized around the State.

${ }^{53}$ Cf. Samuel Huntington, Political Order in Changing Societies. 


\section{CHAPTER III - “Civil Society,” NGOs, and the Globalization of Social Agendas}

The crisis of socialist ideologies together with technological changes and new business administration methods that reduced the role of the industrial workers and weakened the trade union sector led to the "de-radicalization" of party politics and of the left-right schism of the past In order to win elections, parties had to moderate their discourses, navigate among the most diverse interests, and essentially "deradicalize" expectations. Party politics, therefore, entered into a crisis of representation, of expressing the hope of social change or moral guidance in the present.

As political parties gradually were depleted or abandoned for lack of ideological substance, "traditional" politics came to be seen in a negative light, as a sphere characterized by vanity and corruption. Its fall from grace was such that, in the eyes of much of the population of democratic countries, most parties and politicians had forfeited authority, respect and admiration and, at the same time, had abandoned the hope and utopian message associated with them throughout the $20^{\text {th }}$ century. Government office no longer evoked the aurea that the exercise of political functions had commanded in times past when power was viewed as an expression of the divine will and to some extent survived until not to long ago. ${ }^{54}$

For decades, the social democratic synthesis merged social solidarity with an economic policy alternative (Keynesian economics). The combination of redistribution policies and capital formation contributed to a convergence, albeit conflictive, between the interests of the working class and those of the dominant sectors of capitalist societies. To this must be added efforts to accommodate economic progress and social progress and to reconcile technological innovation and social innovation for the common good. Perhaps it was an historical anomaly, that at

\footnotetext{
${ }^{54}$ See Marcel Gauchet, "Quand les droits de l’homme deviennent une politique”.
} 
a particular moment in the development of capitalism, subordinated groups were capable of negotiating with the dominant groups a societal project that benefited the majority of the population. It is not clear if this type of event can be repeated or if this could only have come to pass because the subordinated sectors had attained immense economic-organizational power (through trade unions) and representative power (through political parties).

\section{“Civil Society}

In the current phase of capitalism, we see a growing disconnect between economic progress and institutional systems of solidarity. This disconnect stems from the widening gap between winners and losers (the latter represented by all those whom the economic system has rendered "obsolete" or "non-employable"). The new groups that have been sidelined by the dynamics of contemporary capitalism lack political power and the capacity to bring economic pressure to bear; thus far, they have been unable to translate their interests into a societal project that incorporates their demands into the exigencies of the economic system. While movements such as the Landless People's Movement (Movimento dos Sem Terra -MST of Brazil) or the Zapatistas in Mexico have established themselves as ethical icons or a thorn in the social conscience, they lack the capacity to channel feasible social reform or policy proposals that encompass the majority of the population.

The dissociation between politics and ideals has driven a wedge between the task of government administration, to which political parties must adhere, and the production of moral ideals, a task that has fallen to "civil society" organizations specialized in disseminating a discourse of moral protest. As the producers of "moral causes" increasingly set themselves up as advocates and "representatives" of disadvantaged sectors, the gap widens between the "logic of the system" in which

\footnotetext{
55 For a detailed bibliography and a more updated elaboration of this section see Bernardo Sorj, Civil Societies North-South Relations: NGOs and dependency, The Edelstein Center for Social Research, Working Paper No. 1, 2005. www.bernardosorj.com/pdf/Sorj Article.pdf . For internet available resources on civil society, see OLIVEIRA, Dayse, Research Sites and Researchers on Civil Society and NGOs, The Edelstein Center for Social Research, Research Resources on Internet, Report No.1, 2005. www.centroedelstein.org.br/report/Report civil society.pdf
} 
parliamentary parties are trapped, and the social demands of excluded groups, channeled by nongovernmental organizations and social movements.

Even when certain political demagogues combine a messianic style with moralistic, apolitical discourse divorced from party politics, (such as Collor in Brazil, Fujimori in Peru, or Hugo Chavez in Venezuela), such experiences often are shortlived and rapidly destabilized by the political and economic dynamics at play. In other cases, particularly in developed countries, political parties born of social movements, such as the "Greens," are perpetually torn between the rationales and "purist" demands of their constituents and the practicalities of parliamentary life and forging alliances in government.

This new context also has featured the proliferation of religious groups seeking to increase their influence in public life. While an analysis of this phenomenon is beyond the scope of this work, it is important to contemplate religious groups among the new (or revitalized) actors in contemporary political life, or at least to consider their direct and indirect impact on political representation, particularly taking into account their criticism of the secular values upon which modern citizenship was built.

This "dislocation" of expectations concerning politics is also expressed in the loss of identification with representative political institutions. As a result of this dislocation, we are witnessing a state of apathy, or declining faith in institutions, accompanied by periodic explosions against governments that violate legal or moral principles. When such explosions have occurred-for example, the impeachment of Fernando Collor or the fall of Fujimori in Peru-the mass media, and not political parties or trade unions, have been the main catalysts.

While there is no question that political parties, even as ad hoc instruments of charismatic leaders, continue to be the main mechanism of political representation of the interests and demands of their societies, their capacity to reflect the moral dimensions of politics or to represent the hopes of the most disadvantaged sectors has diminished. The parliament, sandwiched between the Executive Branch with its 
monopoly over material resources and techno-bureaucratic capability and the Judiciary, which is the final arbiter in matters concerning the legality of the laws, becomes increasingly fragmented and colonized by the most diverse economic and social lobbies.

In this way, the space for moral discourse in society gradually has been displaced toward a galaxy of groups referred to as "civil society." These groups have found a powerful spokesman in the press, which serves as an invaluable source of support for their mobilizations and for validating their charges or complaints, which are presented in the name of "absolute moral values".

The emphasis on, and proliferation of, self-described "civil society" organizations is emblematic and a symptom of the working classes' dwindling protagonism, the crisis of political parties, and the growing difficulties governments face in tackling the new challenges posed by societies that are simultaneously fragmented and globalized. In the social imagination, "civil society" gradually has become the only institution espousing political virtues, particularly because it is seemingly "apolitical." It is held up as the new agent of historical transformation and the embodiment of libertarian ideals and aspirations of social justice, in contrast to the inhumanity of the market and the State. Due to the deepening wedge between social activists motivated by an advocacy agenda featuring absolute values and political parties, "civil society" is characterized as the "authentic" representative of "society" in the context of a discredited political system.

As a concept, "civil society" traveled a long road, taking on the most diverse meanings along the way, depending on the role assigned to it by each social philosopher. ${ }^{56}$ But the history of the different uses of the concept of "civil society" has made a limited contibuiton to the understanding of its meaning in contemporary society. In the 1960s and 1970s, the term was used in academic circles particularly related to the significance attributed to it in Marxist-Gramscian thought. But its dissemination in a form more closely resembling the present-day understanding of the term has been in relation to the struggles against authoritarian regimes in Latin

\footnotetext{
${ }^{56}$ See Norberto Bobbio, O conceito de sociedade civil.
} 
America, or in communist countries to describe organized resistance groups in society in confrontation with State power.

More recently, the debate over "civil society" in Latin America has been fostered by social scientists eager to introduce a sociological dimension into the discussion of democratization, in the context of a debate that is largely focused on formal political institutions. These authors apply a concept mainly inspired by the work of Habermas and imbued with strong normative connotations. ${ }^{57}$ It is based on philosophical constructs that, instead of promoting concrete research on "civil society" in all of its diversity and complexity, present hand-picked "case studies" (and the Brazilian experience with participatory budget and the World Social Forum usually are guaranteed a spot) designed to confirm the general theses.

The enormous prestige that "civil society" enjoys today in the mass media and among virtually all international agencies, cooperation agencies and foundations, frequently has led to the acritical or apologetic application of this concept in the social sciences. Therefore, it is imperative to analyze critically the concept, not to discount it, but rather to explain how it is constructed and why it has such a positive status in social imagery and practice.

In recent decades, arguments emanating from political philosophy that aim to reclaim the notion of "civil society" by appealing to a strong normative content seem to us to be very fragile, at least from the sociological standpoint. Such arguments in general involve deductive constructs that ultimately lead to a concept of "civil society" charged with "wishful thinking." For example, Jean Cohen and Andrew Arato, ${ }^{58}$ drawing from Habermas' social theory, try to broaden the horizon of democratic practice by identifying "civil society" as a public, nongovernmental space that coexists side by side with the sphere of private interests (the economy) and the State and political system.

\footnotetext{
${ }^{57} \mathrm{Cf}$. A synthesis of the evolution of this concept in Brazil is found in Sérgio Costa's book, As cores de Ercília.

${ }^{58}$ See Jean Cohen and Andrew Arato, Civil Society and Political Theory. Arato later accepted several criticisms while still maintaining the relevance of the concept. See "Uma reconstituçâo hegeliana da sociedade civil". In Brazil, this view is ma intained by Leo Avritzer, "Alem da dicotomía Estado/mercado" and by Sérgio Costa, op. cit.
} 
According to this perspective, "civil society" is made up of autonomous actors capable of dealing independently with the market or the State and of generating new forms of political participation, social movements and new rights, limiting the trend toward privatization/commercialization and the bureaucratization of social life. There is, as a rule, little clarity regarding the definition of who, specifically, belongs to "civil society." Arato and Cohen, for example, give emphasis to social movements related to new identities, while Habermas focuses more on the role of public space and groups such as nongovernmental organizations (NGOs). In any event, leaving aside the matter of conceptual ambiguity, these analyses are afflicted with the difficulty inherent to the dialogue between social philosophy and sociology, in other words, the problem of identifying concrete social organizations based on theoretical frameworks that define spheres of social action derived from abstract principles. Hence, the three rational dimensions that inform action in modern society-administrative-bureaucratic, market, and social solidarity or inter-communicational-are identified with specific social organizations: the State, the market/corporation, and "civil society." Yet none of these spheres operates in just one dimension (as shown, for example, by the literature from the field of economic sociology on effective business practices) and "civil society" institutions also are not immune to bureaucratic or commercial tendencies.

In social life, no one type of institution holds a monopoly over virtues or vices. The space of the "life-worlds" that Habermas constantly tries to delineate permeates the pores of all social organizations. ${ }^{59}$ Many if not most of "Civil society" organizations, in turn, frequently overlap with trade unions, political parties, churches, or entrepreneurs, or even were created by them, and they also maintain all sorts of ties with the government and the market.

The sociological realities of these organizations vary with each national context and feature many different forms of social and political insertion. The notion that "civil society" constitutes an important component of democratic consolidation is based on the assumption that the diverse subsystems, particularly representative

\footnotetext{
${ }^{59}$ Efforts to link agents of freedom and social autonomy to precise social forms is found even in the work of a prominent author such as Alain Touraine. See Critique de la modernité.
} 
political parties and the judicial system, are functioning properly. If that were the case, "civil society" would be able to act as a transmission belt between the public sphere and the political system. However, this is not the case in most Latin American countries-or even in many advanced countries-where civil society reflects a hypostatic concept that tends to supplant politics with moral discourse or to disregard, as in the case of religious fundamentalist organizations (part of the "civil society" galaxy), basic democratic values.

The idea of a "civil society" distinct from and at variance with, the State is rife with conceptual difficulties, particularly in the Anglo-Saxon tradition, since the notion of State per se is unusual inasmuch as political institutions do not exist independently of society (it is emblematic, for example, that public officials are referred to as "civil servants"). This is not to say that in those countries, the deterioration of party politics discussed earlier has not caused social actors to experience a sense of dissociation from the traditional political system. In the case of countries defined by the continental European tradition, where public administrations inherited a number of privileges and prerogatives from the absolutist State, the critique of the State appears more justified in that it is directed against the persistent authoritarian components and lack of transparency of public administrations.

In the context of the debate surrounding neoliberalism and the way it is played in the media, the concept "civil society" is mobilized as a "third reality" vis-àvis the State and the market. Antiglobalization movements often present themselves as a concrete expression of "civil society," imprinting this concept with the evocative power of an intrinsically good, immaculate social dimension, untainted by the evils of the State or the market. In reality, political parties-which also create their own NGOs-have appropriated the "civil society" discourse, just as it has become commonplace for politicians and government officials to participate in the meetings of the World Social Forum, which is financed mainly with public sources..

As "civil society" becomes increasingly removed from the political system, and from the political party system in particular, the parliamentary sphere is diminished in importance, social fragmentation intensifies, and the capacity to 
develop societal projects is diluted. In the final instance, what emerges is the non idemocratic illusion of a "civil society" able to exist with its back to the State.

The use of the concept of "civil society" by some of its self-proclaimed representatives is tantamount to a negation of the concept of public space. If "civil society" is a dimension of the public sphere, then it cannot be "represented" by any group, as that would mean a contradiction with the notion of an open sphere. The public sphere is public in that it constitutes a space for dialogue and for the debate of conflicting opinions; no one can represent it and no actor can appropriate it without attacking its very foundations, homogenizing a reality whose essential condition is diversity. ${ }^{60}$

The self-representation of "civil society" as a homogeneous structure contributes to this tendency. Since it does not represent itself as a party (in other words a part) relative to others, organizations that belong to "civil society" don't need to confront their peers and define themselves in contrast to the State and the market.

The temptation of civil society organizations to assert a monopoly over the public sphere appears stronger in countries with fragile democratic institutions or authoritarian regimes, it is also present in most "civil society" organizations that claim to embody absolute values to the detriment of political parties. In doing so, such organizations can undermine the role of the public sphere as a space for dialogue and the development of policy alternatives and may end up corroding democracy, itself a prerequisite for the existence of an autonomous "civil society."

Meanwhile, in countries where democratic society is firmly entrenched, very few NGOs question the specific role and legitimacy of the political system. This is not the case in Latin American countries, much less in African countries. When governments enjoy scant legitimacy or are undemocratic, "civil society" tends to

\footnotetext{
${ }^{60}$ The closest thing to a "representation" of the public sphere is the statistical metaphor of the "public opinion" poll, which should never be confused with the public sphere as such.
} 
consider itself "more" legitimate than the government itself. In certain situations, even armed groups such as the FARC in Colombia claim to represent "civil society." While this political "substitutionism" is inevitable in undemocratic contexts, in democratic regimes it represents a return to practices that could open the door to authoritarian, messianic approaches.

One of the problems with how "civil society" uses the discourse of human rights lies in its political manipulation. Human rights organizations frequently mask clearly defined partisan political agendas, whose priorities are a far cry from those of the universality of extolled values, as was evident during the 2001 conference against racism in Durban. The logic behind these organizations is no different than that of the communist-sponsored "fronts" of years past in that they employ a discourse that condemns the failure to respect human rights, but is associated, in fact, with the struggle against the "political enemy."

"Civil society" organizations and actions should therefore be examined in their specific political and social contexts. Their demands or claims, and utopias may be-and usually are-core components of democratic revitalization inasmuch as they create and defend new rights and values. However, in certain cases, "civil society" actions may, directly or indirectly, advocate authoritarian and reactionary regimes, as demonstrated in past and recent history, from extreme right-wing groups to religious fundamentalists.

The prestige accorded "civil society" is a reflection of its significance as a source of new social practices and a gauge of society's dissatisfaction with its political institutions. In practice, relations between political parties and "civil society" tend to be simultaneously complementary and conflictive. Complementary in that political parties (and governments) act as parasites on "civil society" in their efforts to identify new issues and causes through which to preserve their moral authority, after they themselves have depleted the ideologies that once nourished their creativity and vision for the future. 
Although some "civil society" organizations tend to undercut the legitimacy of political parties and established governments, they do not pose a threat to consolidated democratic regimes. They do, however, have the potential to demoralize political life in countries with less solid democracies.

In democratic systems, the convergence of solidarity and individuality, or common values and respect for individual autonomy, is ensured by means of electoral mechanisms through which citizens empower their chosen parties and politicians to defend their particular (individual) and common (group or societal) interests. For a long time, political parties set themselves up as the main collective vehicle for individual expression through collective means as well as being a transmitor of overarching causes or groups interests. The wedge dividing the human rights organizations and the elected political representatives is both cause and symptom of the crisis of political party representation. This conflict is most obvious when the organized expression of "civil society" is primarily NGOs comprising of an extremely limited number of individuals.

\section{The World of NGOs}

NGOs refer to a broad range of institutions which significantly, are defined in negative terms, as private, non-profit organizations. In practice, this universe cuts across the spectrum, from the more traditional, usually volunteer-based philanthropic religious organizations, to foundations and neighborhood associations, and on to what are best described as front organizations, either of politicians who use them to channel public resources or entrepreneurs who regard them as a more lucrative business management approach. ${ }^{61}$

Despite the continuity between traditional forms of philanthropic activity and NGOs, the "modern" NGO, which has proliferated since the 1970 s, is a novel social type of organization and political culture. The contemporary NGO is an institution specialized in the creation, defense, and dissemination of human rights, and often

\footnotetext{
${ }^{61}$ On the global dimensions of this sector and the representation of certain national cases, cf. Lester M. Salaman et al., La Sociedad Civil Global: las dimensiones del sector no lucrativo.
} 
claims a monopoly in that area of political discourse. In contrast to traditional civil society organizations (from community based organizations and religious groups to professional organizations and trade unions) they do not represent, nor are they chosen by, the public they claim to represent. ${ }^{62}$ NGOs could be more aptly defined as non-representative political organizations whith legitimacy based on universal moral claims.

Organizationally, NGOs usually are populated by professionals devoted exclusively to "social causes." Behind the NGOs there is a new international actor, one that requires more detailed research and analysis: the galaxy of private foundations and international cooperation resources (both from national states and international agencies) who play a major role in defining the agendas of NGOs, particularly in developing countries.

There are many different types of NGOs, most of them "dwarfs" (consisting of one or two people). One possible typology refers to ascription or origin: there are PNGOs (linked to political parties), BNGOs (associated with business or company offshoots), RNGOs (associated with religious groups), UNGOs (related to trade unions), and so forth. Other classification approaches focus on a) whether they are local, national, or transnational; b) their voluntary or professional nature; c) their sphere of action. These categories illustrate the different tracks guiding these organizations, but in practice, most NGOs do not follow a "pure" model of organization or action.

We can identify two ideal type of NGOs: those focused on defending causes (advocacy groups) and those engaged in developing "exemplary" social practices. The main objective of the former is to carry out activities with a media impact, as a way of mobilizing public opinion around their causes aiming to change policies. The latter group is engaged in the development of concrete social projects, which does not rule out the objective of galvanizing public opinion around their targets of action.

\footnotetext{
${ }^{62}$ Philantropic organizations also do not represent their constituencies, but they do not claim to do so.
} 
The NGO world does not represent a closed world inasmuch as it cultivates a variety of relationships-many of which involve direct dependence-with other social spheres. This situation, which in principle is positive, requires a thorough and specific examination of the role played by NGOs in each social context, as opposed to simply elevating them to the status of new agent of historical progress.

International insertion is a typical feature of most NGOs. As Sérgio Costa points out,

[...] only by taking into account the complex game of interpenetrations, social alliances, and transnational alliances is it possible to understand, for example, why issues such as the environment, gender equality, or the struggle against racial discrimination gained a disproportionate level of importance on the Brazilian political and academic agenda relative to the political weight of the social actors they represent in the national context. ${ }^{63}$

The international insertion of most NGOs in developing countries was built on grants earmarked for specific agendas. In a sense, then, the NGO world replicated North-South inequalities. Most NGO agendas (for example, those working on environmental issues or birth control policies) reflect the concerns, sensibilities, and priorities established in the ir headquarters in the developed world. . Assistance is not always imposed, but their dependency on international funding cannot fail to influence the positions taken by NGOs in less developed countries, in some cases creating local "enclaves" of executors of an agenda defined overseas.

While there are no systematic international studies on the social make-up and backgrounds of NGO leaders and members, isolated studies have shown that, besides serving as a critical source of employment for local leaders from poor neighborhoods or for ethnic minorities, NGOs absorb a significant quantity of college graduates, particularly in the social sciences. In recent years, university courses designed specifically to train future NGO professionals have emerged around the world.

\footnotetext{
${ }^{63}$ See Sergio Costa, "A construçao de raça no Brasil".
} 
The role and political influence of NGOs in a particular society, as we already have pointed out with respect to "civil society," depend on the societal context (in most fundamentalist Muslim countries, Syria, China, and Cuba they are, as a rule, either prohibited or State controled). In many parts of Africa, NGOs, where allowed to function, absorb a significant portion of middle class professionals. Supported virtually in their entirety through external funding, they offer "international" salaries, meaning a much higher salary than those earned by public officials. This enables their members to preserve a certain degree of autonomy and a critical distance from the widespread corruption in public administration. In Africa NGO budgets are expanding - a significant portion of international cooperation funding currently is allocated directly to "civil society"- thereby transforming these organizations into genuine power centers with enough clout to que stion the legitimacy of established governments in international forums.

In Latin America, NGOs generally have less political weight, although their numbr has increased on the tide of democratization processes and deepening social problems, including urban breakdown and spiraling violence. For their part, governments and international agencies turn to NGOs to carry out specific, creative actions, which they make use of to offset dwindling resources and bureaucratic pigheadedness and corruption.

The universe of the NGOs in Latin America has become tremendously diversified since the 1970s when they were funded mainly through external sources and devoted to resist authoritarian regimes. In recent decades, the relative importance of foreign funding has declined, while public funding sources are on the rise, as is support from the business sector, which, influenced by the socially responsible company discourse, has significantly increased its involvement in social projects.

NGOs in Europe, while retaining their significance as sources of employment have less political influence due to the greater solidity of the State-run social services system. In some countries, such as France, NGOs subcontract with the State and/or lay the groundwork for the entry of public services in "difficult" neighborhoods. 
Many of the mainstream NGOs in developed countries focus primarily on international cooperation.

Although the complex relationship between the media and democracy has inspired an enormous body of literature and sparked numerous debates that are beyond the scope of this essay, it is important to note the affinity that exists between the mass media and processes that have contributed to the strengthening of "civil society" and the NGOs. Despite the major, obvious differences between these two actors, they share a powerful affinity: both reproduce and expand their radius of influence thanks to the growing rift between public opinion sensibility and politicalparties capacity to express it.

NGOs depend on access to the media because they lack their own social "bases" and because their ties to their potential constituencies are fragile or are activated in function of specific events. Indeed, the social groups they seek to represent often are unstructured and in most cases lack the resources to directly influence the economic or political system. For this reason, some of their activities are oriented toward achieving an impact in the media. Their very existence is tied to their ability to generate press coverage, even if that means resorting to sensationalism, which sometimes entails acting on the margins of legality, as illustrated, for example, by the actions of certain environmental groups.

In contemporary democratic societies, the media are particularly sensitive to messages involving strong moral content. . Put another way, because of their selfproclaimed role as society's conscience and their real capacity to influence public opinion, the mass media tend to represent themselves as the moral expression of society. However, despite their important social role, the media end up supplanting authentic mechanisms for participation and political discussion.

Most self-proclaimed "civil society" organizations, as we have seen, take a clear stance against neoliberalism and, in general, against globalization. In the past decade, however, the international and corporate institutions associated with 
neoliberalism and globalization have waged a crusade against government inefficiency and corruption, including the state role as the direct producer of public goods and services. These institutions, therefore, appropriate "civil society's" criticism of the State and are even willing to fund "civil society" organizations in order to shrink the government's role by diverting its responsibilities to the NGOs.

Indeed, compared to the inertia of the government apparatus, NGOs have the advantage of enormous flexibility and creativity. They are, in addition, social advocates and laboratories for new practices and solutions to the challenges of a mutating world that is constantly faced with new problems. The market equivalent to the work of NGOs in the public sphere are "start-up" companies (small enterprises with enormous capacity for technological innovation), since large corporations face the same problem as the government apparatus: the weight of internal inertia. Nonetheless, while in the case of "start-ups," market dynamics are more inclined to assimilate successful experiments by large corporations, this dynamic is more complicated in the realm of NGO-government relations. In effect, the danger is that, taking into account the scarcity of resources and its own political priorities, the State will use NGOs to relinquish its own responsibilities and, rather than assimilate successful initiatives, will simply "showcase" isolated experiences.

The challenge, then, is to connect horizontal networks (represented by socially porous NGOs with local mobilizing capacity) to the vertical structures of the State, with its resources and national scope, and create a virtuous circle in which their respective spheres are respected. ${ }^{64}$ Otherwise, the work of the NGOs will have the paradoxical effect of increasing the heterogeneity and gaps within the poorest social sectors since, in most cases, the ir activities are concentrated in major cities and operate in certain population groups boasting enterprising local leaders or the ability to absorb NGO programs. Obviously the intention here is not to negate the concrete value of such initiatives, but rather to keep in mind that reducing social inequality is largely contingent upon government initiatives targeting systematically social sectors

\footnotetext{
${ }^{64}$ Cf. Bernardo Sorj, brazil@digitaldivide.com- Confronting Inequality in the Information Society (available at www.bernardosorj.com) .
} 
less equipped to absorb external assistance, develop proposals, or articulate demands for resources.

Another problem posed by NGOs is that of representation. Essentially, they do not base their legitimacy on the number of citizens they represent, but rather on a moral ethos and on the intrinsic value of their causes. When certain NGOs and other "civil society" organizations represent themselves as the expression of "organized civil society," they reproduce all of the errors and defects of the old vanguardist organizations in that they assume the preexistence of a disorganized, homogeneous, and naturally virtuous "civil society" that only needs to be given a voice. But on what criterion is one NGO more representative than another? What is the basis for one NGO's legitimacy, and not another's, to "represent" a "cause" in national or international fora?

Some authors believe that NGOs are the cornerstone of a future international "civil society." This vision is legitimate as an expression of utopian intent, ${ }^{65}$ but when it is confused with concrete reality, whether by activists or sociologists, ${ }^{66}$ it becomes analytically unsustainable and politically irresponsible. Certain theorists, swayed by the notion of a global "civil society," hastily discard the State in their visions of a cosmopolitan society constructed on an NGO scaffolding. However, NGOs mirror the asymmetries of the international system and the national diversity of democratic consolidation.

Finally, the third problem concerns some NGOs' use of the concept of empowerment. This concept, disseminated primarily by the North American feminist movement, is cultivated today by U.S. foundations and international agencies. The difficulty of translating this Anglo-saxon concept into Latin languages is indicative of its links to a given political tradition. In some sense, the notion of empowerment seems to be the liberal-radical equivalent to a variation of Marxist "class consciousness"- which defines social class as a reality that predates its consciousness of itself. Both cases assume the preexistence of the dominated group,

\footnotetext{
${ }^{65}$ Such as that expressed, for example, by Rubem César Fernandes in "Threads of Planetary Citizenship".

${ }^{66}$ For example, Ulrich Beck, op. cit.
} 
which needs only to be equipped with the right tools in order to take its destiny into its own hands. In the case of empowerment, then, women, African Americans, and indigenous peoples are, for example, subordinated groups who can be enlightened so that they begin to promote their own interests as specific identity groups.

The ideology of empowerment echoes the mistakes of Marxist ideology; in other words, it assumes that the group existence predates the ideology and that someone coming in from the outside is in a position to discern the true identity of the oppressed. This contradiction, which is inherent to any type of social intervention that extends beyond the parameters of its own group, poses enormous risks. And since these risks are inevitable, social action projects must constantly reflect on them. The first risk is that of external colonization, due to the export of archetypical identities that emerged in very different societal contexts. The second is the imposition of a political model foreign to local traditions, which serves to further undermine the political representation system of subordinated groups, if not destabilize the entire political system.

Sociological analysis on NGOs and "civil society" is still in its incipient stages. It will be necessary to conduct meticulous research in areas such as political encapsulation processes, channeling and control of national and international resources, internal organizational structures and operations, in sum, on internal and external power relations and the new types of bureaucratization they engender. Critical social analysis should not fail to question the processes that inform the discourse on international "civil society," the issues discussed at its forums and how they reproduce the power relations that criss-cross society and the international system. Critical analysis of NGOs in no way implies discounting their role as one of the main vectors of contemporary collective solidarity, social innovation, and new democratic practices, whether that be as generators of unprecedented social reconstruction proposals, or as promoters or catalysts of authentic social movements or humanitarian actions. 


\section{Reconstructing the World through Human Rights or the Market?}

The general heading of the "populist period" is used to describe an era that lasted throughout much of the $20^{\text {th }}$ century, during which Latin American countries processed the political and social integration of the lower classes into a civil rights system. These integration processes varied enormously from country to country. In some instances, social integration-particularly in terms of access to education and health-was extremely broad and successful, such as in Argentina, due particularly to the trade union influence in a society that was early urbanized, with a limited labor force. But Argentina failed to consolidate a sense of national civic community due to the chasm opened up in the political culture by Peronism, which itself had been nourished on the legacy of a reactionary elite (including the Catholic church and part of the armed forces) and the misadventures of the radical party in the 1920s.

In other cases, such as Brazil, extreme social inequality and the population's limited access to public services was offset, in part, by a long cicle of economic expansion an open frontier, along with a syncretic religious culture, the racial mix, social and geographical mobility, the emergence of an urban middle class accessible to the lower classes, and a cultural industry that created potential opportunities for interactions across class lines. Due to these factors, the enormous social and economic gap did not translate into a cultural gap and this, undoubtedly, is one of the main virtues of Brazilian sociability.

The Andean world presents very diverse traits. Following the Pacific War, Chile, with its centralized State, demonstrated its enormous capacity for political integration and the generation of national values, despite extreme social inequality. In contrast, in countries such as Bolivia and Ecuador, indigenous populations bore the brunt of a system of large landholdings that left them socially and culturally isolated from a sense of belonging to a national community of citizens. To give just one final example, Uruguay and Costa Rica appear to have had the most success in terms of social, political, and cultural integration. 
All of these social integration models collapsed in the 1960s and 1970s, as economic growth trends stalled and it became impossible to maintain the traditional systems of using public resources to co-opt emergent sectors. The urban explosion, raised expectations, and the expansion of democratic values contributed to the crisis of the economic growth model and of the system to integrate the middle and working classes, a crisis which took the form of galloping inflation and economic stagnation.

Inflation was the main symptom of the incapacity of States' to impose discipline on the distributive conflict. It also encouraged profiteers and speculators, dealing a harsh blow to the most impoverished sectors of the population. At the time, the only recipe book available for fighting inflation and securing international loans-developed by international finance institutions and endorsed primarily by the United States-recommended a structural reform package to reduce government spending. This was accomplished through privatization, social security and tax reform, greater economic opening to foreign markets, and labor law reform.

It was an agenda destined to radically transform the social integration model in place in Latin America up until then, in which the State played a protagonist role in the cooptation of emergent social groups. It was possible to implement this new agenda because the old model had been exhausted; it had come to be seen by an increasing number of social sectors as a system for doling out favors, incapable of generating economic growth or ensuring universal access to quality public services. Put another way, people accepted - and even lent their support-to many structural reforms, including privatization initiatives, not only because they were presented as necessary to control inflation, but because the State, which had been key to Latin American development in the $20^{\text {th }}$ century, came to be perceived as a source of cronyism, corruption, ineffectiveness, and bureaucratic oppression.

Although the structural reforms program was carried out, to varying degrees of intensity, throughout Latin America, it had a different impact in each country. ${ }^{67}$ The repercussions would depend on the coverage of social rights prior to the reforms

\footnotetext{
${ }^{67}$ Regarding economic reform processes in Latin America, see Juan Carlos Torre, El proceso político de las reformas económicas en América Latina.
} 
(for example, the impact in Argentina, where most salaried employees had been integrated into the social security system, was very different than that in Peru or Brazil, where a substantial portion of the urban population belonged to the "informal" sector). The final outcomes of these changes also would depend on how the privatization efforts were carried out and how the regulatory agencies overseeing public service contracts were set up (in this regard, there are obvious differences between the Menem administration's organized assault on the public coffers and the "civility" of the democratic governments in post-Pinochet Chile and the Fernando Henrique Cardoso administration in Brazil). To this must be added the differences in social policies (for example, while primary and secondary public education expanded in Brazil in the 1990s in absolute and relative terms, this sector underwent a strong privatization process in most countries on the continent.) ${ }^{68}$

As a whole, structural reforms did not bring about greater social equality. As a result, international economists and institutions, the World Bank in particular, began to promote "focal policies," meaning that State resources should concentrate on well-defined "target publics," usually the most impoverished sectors of the population or specific groups (women, ethnic groups, etc.).

The opposition between universal service coverage policies and focal policies that informs the debate among economists in Latin America today, clouds rather than clarifies the problems at issue here. In effect, no society has only universal services or only "focal policies." The United States, home of the "focal policies," provides some universal services. In Europe and Canada, focal policies go hand in hand with the predominant universal service policies. While comparative examinations tend to gloss over countless historical factors, their findings in terms of social equality and return on investment (particularly in the area of health) support the universal services approach. The Achilles heel of this model, however, is its sustainability in a context of increased longevity and lower birth rates. Moreover, in countries such as Brazil, seemingly universal policies mask more targeted practices that accord preferential treatment to the richest social segments of the population, like free public university.

\footnotetext{
${ }^{68}$ See Bernardo Sorj, "La relación público/privado en el Brasil".
} 
In any event, the structural reforms marked a turning point in Latin American history, calling into question a model informed by State-centrism. The integration of new generations of middle classes into the international business and services circuit, societies with expectations determined by global consumption patterns, and the waning legitimacy of politics and politicians have shaken the relations between the State, society, and different social groups, and call for a redefinition of those relations. This process is currently underway although there increasing signs of return to new (and old) forms of state-centrism.

But even when the so-called structural reforms have represented a step toward greater state and social discipline, they did not constitute a proposal for the organization of society. Realizing that economic reforms had not changed customary practices concerning the use of public resources or ameliorated social problems, international agencies began to acknowledge that there was an issue that needed to be addressed along with the economic reforms. If the orginal reforms proposals put forth by international financial institutions already were problematic from the economic standpoint due to their propensity to apply a universal recipe blind to specific national realities, when it came time to address institutional issues, with their inherently strong ties to local historical circumstances, the resulting proposals were more unfortunate still.

The new institutional agenda focused basically on mobilizing two types of concepts and proposals: a) strengthening "civil society" and "social capital,"69 applying, in both instances, concepts that would not interfere with the market or the distribution of wealth yet would miraculously improve society; and b) the use of institutional "best practices" and "benchmarks" for public services, including health, education, and justice.

For instance, the elixir of "social capital accomplishes the following: ${ }^{70}$

\footnotetext{
${ }^{69}$ See, respectively, www.worldbank.org/civilsociety and www.worldbank.org/wbp/scapital.

${ }^{70}$ http://www.worldbank.org/wbp/scapital/topic/
} 
"Crime/violence: Shared values and norms can reduce or keep low the level of community violence. People who have informal relations with their neighbors can look out for each other and 'police' their neighborhoods

Economics \& trade: There is increasing evidence that trade at the macro level is influenced by social capital --a common property resource whose value depends on the level of interaction between people.

Education: Considerable evidence shows that family, community and state involvement in education improves outcomes.

Environment: Common property resource management entails cooperation with a view to ensure the sustainability of resources for the benefit of all community members, in the present and in the future.

Finance: A stable, secure and equitable financial system is a precursor for sustainable growth. Health, nutrition \& population: Recent research shows that the lower the trust among citizens, the higher the average mortality rate.

Information technology: ...information technology has the potential to increase social capital - and in particular bridging social capital which connects actors to resources, relationships and information beyond their immediate environment.

Poverty \& econonomic Development: ...development and growth specialists are uncovering the importance of social cohesion for societies to prosper economically and for development to be sustainable.

Rural development: Social capital is significant because it affects rural people's capacity to organize for development. Social capital helps groups to perform the key development tasks effectively and efficiently.

Urban development: Urban areas, with their anonymity and fast pace, can be unconducive to societal cooperation. Social capital and trust are more difficult to develop and sustain in large groups. 
Water supply \& sanitation: Social capital contributes to the sharing of information about sanitation as well as the building of community infrastructure."

The concept of social capital was drawn from a specific theoretical framework, namely, methodological individualism, and subsequently was associated with studies contrasting northern and southern Italy. ${ }^{71}$ It is essentially an elaboration of the obvious: a society functions better when its members trust each other; horizontal associativism and cooperation enhance information and social opportunities; and, respect for civic values is a factor in development. At its core, the concept of social capital stresses contemporary social relations and cultural orientations as opposed to formal institutions. Its purpose as an economic development tool is to seek out (and strengthen) virtuous factors external to government institutions.

Transformed into a universal paradigm and delinked from contexts and institutions and from the complex and varied relationships of values presented in every society, like trust/distrust, equality, hierarchy, group solidarity/distrust of others, the concept of social capital fails to incorporate the rich experiences of other cultures. For instance in many Asian countries systems of hierarchical relationships have proved highly effective in promoting economic growth and social equality while in other contexts may provoke state failure.

Studies on social capital operate on the assumption that affiliation with voluntary organizations is a universal measure of the development of horizontal relationships characterized by openness and trust among community members. Yet it is a measure that fails to consider the motives that might lead a person to affiliate with voluntary organizations. For example, in North American societies, where people are constantly changing residence, affiliation with voluntary organizations is a mechanism for establishing social relations. Therefore, it does not necessarily indicate a higher level of trust than that observed in communities featuring less geographical movement, where people do not have to join formal organizations in

\footnotetext{
${ }^{71}$ See James Coleman, Foundations of Social Theory, and Robert Putnam, Making Democracy Work
} 
order to maintain high levels of trust among themselves (for example, in Japan, Finland, Switzerland, and Germany).

Every society is built around values of trust and distrust and both are equally necessary for a social life but they ultimately depend on and express the overall functioning of institutions and public sanction. The irony is that lack of trust in government institutions frequently is conducive to the high value placed on interpersonal relationships and, as such, is a source of social capital, while trust in effective law enforcement may reduce the subjective intensity of personal relationships. In contexts featuring the essentially anonymous relationships common to contemporary societies, trust in contracts is based on the certainty that government institutions will ensure their enforcement and that illegal acts will not go unpunished. To summarize, it is theoretically and practically impossible to separate out the overlap between government institutions and behavior patterns or between trust among individuals and trust in the public order.

If the elaboration of concepts lacking theoretical substance is nothing more than an intellectual non starter, the adoption of public service models extracted from other contexts entails obvious risks. To think that best practices and benchmarks (cases representing the best positions achieved in a given sector) can be mined from their society of origin and transferred just like that to other local realities is an affront to the social sciences accumulated knowledge. This, not to mention that benchmarks and best practices are, as a rule, highly simplified models of complex experiences along the lines of self-help books, in this case, applied not to individual but to whole societies.

Besides its intellectual dimension there is another factor, of political nature, inasmuch as benchmarks generally are extracted generally from within one particular society, the United States, which features, relative to other developed countries, high levels of social inequality and one of the worst track records in terms of the efficiency in its health and education systems. 
Clearly, our sociological understanding of how international financial institutions operate is precarious, and this makes it hard to explain their intellectual primitivism when it comes to understand how institutions work. We know that one part of the problem can be attributed to the influence of U.S. policy and another to the fact that these institutions are run by economists with limited sociological sensitivity, but much of the problem must be ascribed to an underlying logic of globalized action in which concepts and methods acquire a universal applicability. However, in contrast to the logic of multinational corporations which will be penalized byt the market if they fail and therefore try to adapt to local market realities, in the case of international financial institutions the costs are absorbed by the recipient countries, which must accede to the imposition of conditions under which they will be able to receive funding. Those models periodically demonstrate their unsuitability, eventually leading the international institutions to discard the "old" concepts and create a new method that will set in motion a new cycle of experiences.

\section{International Public Opinion and National Governments}

Since its origins in the 18th century, public opinion has been a transnational, intra-European phenomenon with repercussions for the colonial elites. In the 19th and 20th centuries, international public opinion was shaped by the main political ideologies-Liberalism, Nationalism, Socialism, and Communism-and channeled mainly through political parties and social movements (like, for example, the feminist struggle for universal suffrage).

In the past, national public opinion was associated with political parties and expressed through platforms containing proposals for how society and government should be organized. In contrast, public opinion today is associated with "civil society," organized around issue-specific demands directed toward the State, and frequently mobilized through media events. While the old public opinion was ideologically-based and demanded power and/or government reform, civil societycentered public opinion is organized around mobilizations against the government or 
demands or claims directed toward the government. Although the new public opinion is capable of reforming certain public administration practices, at the same time, its discourse has the potential to depoliticize citizens and delegitimize political institutions. Human rights ideology and related civil society organizations delink the social sphere from the State and the nation, while new social rights-centered struggles discredit the notion of interest.

The State continues to have operational legitimacy —in other words, it is still expected to maintain order and ensure public services and economic growth-but it has lost its halo of transcendental legitimacy historically associated with its role as representative of the fatherland and the nation values. The professionalism of armies observed in virtually all developed countries and the end of obligatory military service are the most obvious symptoms of the end of an era.

However international relations continue to be structured around the notion of national interests and the willingness of States to defend them. ${ }^{72}$ Human rights and democracy, that is, the use of negotiation to create consensus, can only be fully effective inside a democratic society while, at the international level, the struggle for human rights and democracy coexist with realities that require the pragmatic defense of national interests.

In developed countries, this two-tiered reality of national and international political life historically was evident in the coexistence between internal democracy and external nationalism. As nationalism ceased to be in many countries, in particularly in Europe and Japan, a driving force, the ability of national governments to act effectively, including the use of military force, has diminished gradually.

Deinstitutionalization processes — through which the State forfeits its role as the representative of the general interest, increasingly incapable of uniting the population around patriotic and national values and interests heretofore considered

\footnotetext{
${ }^{72}$ Even by going to war, based on the public's willingness to accept that citizens "die for their country," in other words, an expression of a collective interest.
} 
sacred and worth fighting and dying for-are particularly advanced in Europe and Japan, influenced by the traumatic experience of World War II and the colonial wars.

European construction involved abandoning nationalisms and references to a history of wars that no longer can be portrayed as glorious experiences since yesterday's enemies are today's members of the same polity. It is no coincidence that in the European Union, the United Kingdom—a country that emerged from World War II with its national self-esteem reinforced-has the greatest military capacity and a strong sense of national sovereignty. The French strategy, in contrast, has been fraught with ambiguity. Since the Napoleonic wars, France has experienced a relative decline in the international theater due to its waning demographic and economic influence. Following World War II, it entered into a preferential alliance with Germany and tried to solidify its position through the strengthening of Europe, in an attempt to preserve its status as a protagonist country. Implicit in this strategy is the capacity to control or lead the European Union, an increasingly difficult task, since the EU currently is made up of 27 very disparate countries.

The creation of the European common market was premised on the rise of the human rights discourse and the decline of nationalism and national sovereignty. The European Union has tremendous difficulty generating any political will beyond purely economic interests. The geopolitical paralysis induced by this situation was manifest during the crisis in Yugoslavia, when genocide occurring on the very borders of the European Union was confronted only after the United States, through NATO, imposed a military intervention outside the United Nations framework. ${ }^{73}$

\footnotetext{
${ }^{73}$ For a comparison between Europe and the United States based on a critique of the European position, see Robert Kagan, Of Paradise and Power.
} 


\section{Social Transformations and the Judicialization of Social Conflict in Latin} America

The exercise of power, as Michel Crozier taught us, is the ability to control sources of uncertainty and transfer the cost of the unpredictable to other individuals or social groups. The revolution in modern law imposed a state of universal legal uncertainty on social groups, including the elite. In other words, before the law every person was equal and could expect similar punishment. This meant establishing a system for meting out justice that was immune to the transfer of economic or political power and therefore, obliged those sectors to accept a situation of equality and uncertainty vis-à-vis the legal process. In the liberal vision, the law must ensure its universal nature by according everyone the same treatment; in other words, it cannot allow unequal access to power in other spheres (economic, political and cultural) to invade the legal sphere. ${ }^{74}$ As we have seen, equality before the law was enhanced by the establishment of compensatory mechanisms for regulating contractual relationships between parties with uneven bargaining power.

The advance of the judicialization of social conflict differs among countries and regions. In Latin America the judicialization of social conflict was radicalized by the convergence of, at least, four specific factors:

1) The new constitutions drafted in the aftermath of the cycle of dictatorships of the 1970s and 1980s strengthened the role of constitutional courts, created new entities for the defense of citizen rights, and broadened the rights enshrined in the constitution. $^{75}$

2) Laws created for a particular political juncture, in function of the economic imperative to fight inflation and stabilize the currency, led to legislative inflation and pitted citizens and companies against the Legislative and Executive Branches, thereby transforming the Judiciary into the arbiter of social conflict.

\footnotetext{
${ }^{74}$ See Michael Walzer, Spheres of Justice.

${ }^{75}$ For an optimistic view of judicialization processes in Brazilian society, see Luiz Werneck Vianna et al., Corpo e alma da magistratura brasileira. Rogério Bastos Arantes offers a critique of the constitutional control system in Judiciário e política no Brasil.
} 
3) Ironically, the judicialization of social conflict has evolved at a time when a significant portion of the working population across the continent is experiencing a sense of lost rights (including those in the areas of labor and social security). Paralleling this very real loss of rights was an expansion of rights in other areas (for example, the rights of women and children, or cultural and environmental rights). Therefore, we have before us, in part, a loss of rights (some of which included corporativits privileges), but also a dislocation of rights, from organized labor to the very poor (through policies of cash transfer). .

4) In Latin America, the practice of impunity neutralizes the rule of law and diverts legal power from other spheres of authority (political or economic) undercutting the universal nature of the legal system.

The judicialization of conflict in Latin America cannot be reduced either to a simply positive or negative process. It is, rather, an expression of the democratization of society (the widespread sentiment that each individual deserves equal rights and minimum social conditions) and it fills the vacuum created by political institutions incapable of organizing social conflict within the political party framework.

The gap — and for the poorest a veritable abyss— between the world of law and social reality, seems then to recreate (under new terms) the old dichotomy described by Domingo Faustino Sarmiento. ${ }^{76}$ According to this Argentine politician and intellectual, Latin America is condemned to oscillate between civilization and barbarity, between European values and the social reality of the masses across the continent, between liberal constitutions and peoples incapable of exercising democracy (a result of the hostility of life on the pampas, the exuberance of tropical rainforests, or the oppression to which the indigenous peoples and slaves were condemned, among other reasons).

\footnotetext{
${ }^{76}$ Regarding the portrayal of Argentina's history based on Sarmiento's work, see Maristella Svampa, El dilema argentino.
} 
The contemporary "progressive" version of this perspective asserts that barbarity is the product of the social exclusion produced by the neoliberal model. According to this view, collective actors and grassroots social movements are essentially virtuous, but the policies imposed by international agencies at the service of a particular globalization model generate poverty, misery, social exclusion, and growing social inequality, which chip away at democratic functioning, thus creating the potential for individual and/or collective violence.

Contemporary Latin American societies, however, have undergone profound changes. The dichotomous vision contrasting a "real" social world with a "formal" legal world no longer applies, just as the notion of a "profound" and virtuous reality whose potential accomplishments are thwarted by external factors has been debunked. ${ }^{77}$

From the moment the contrast between the real society and the formal institutions stopped serving as the yardstick for understanding where we are and what we need in order to arrive at the "ideal point"-based on a paradigm in which the sociologist could demonstrate the true phase of society while the "positivist" jurist appeared to live in a castle lacking social foundations-we have to develop new explanatory models. Rather than resort to new versions of the same old dichotomy between the formal legal world and the real social world, we should explain the paradox of a society that would like to be egalitarian, upholding and identifying strongly with liberal and social justice values, but continues to generate inequality and violate the norms of social coexistence.

\section{Citizenship in Latin America: Variations on Modernity}

As we saw in the first chapter, citizenship was created in the framework of national communities, based on shared values that were rooted in the history of nationbuilding and in general, related back to a founding myth. In a sense, citizenship in Latin America was condemned, albeit in the changing contexts of each country and

\footnotetext{
${ }^{77}$ See for instance Angelina Peralva's analysis of the paradoxical relationship between democracy and rising violence in Brazil in Violência e democracia.
} 
time period, to vacillate between the idea of a desirable citizenship and society, according to a foreign model, and the search for an authentic national culture upon which the inherent nature of the social collective could be built.

Up until the second half of the $20^{\text {th }}$ century, Europe, more than the United States, was the main source of inspiration for Latin American elites. For the elites, achieving modernity meant forgetting the indigenous or African past and rebuilding the national community based on "European ideals". ${ }^{78}$ The socialist and communist parties did not in general deviate from the tendency to disparage the past and adopted a discourse in which the popular culture had to be purged of its spurious elements, particularly religion. ${ }^{79}$

Periodic attempts were made to recover the cultural world of the oppressed in Latin America. This recovery found its first significant expression in the Hispanic American indigenous-centered movement of the early $20^{\text {th }}$ century, while its broadest cultural impact has been associated with the Mexican Revolution and its many artistic manifestations, conceptualized by José Vasconcellos based on the notion of a new "universal race." But such efforts, revitalized by nationalistic movements, failed to modify the dominant mimetic hope of repeating locally the dominant communist or capitalist models available at the time.

This vocation for imitation varied according to country and time period, just as the dissatisfaction with "what we are" had a tendency to change its target. Into this space of dissatisfaction between what we are and what we would like to be, was inserted the hypertrophic expectations of salvation of each new government and the feeling of living in a society that always falls short of its desires.

The constant wish to be a mirror image of advanced or revolutionary countries was apparent even in the social sciences, which were split between a

\footnotetext{
${ }^{78}$ The schizophrenia of the Latin American political elite was masterfully portrayed in literature, in particular in El siglo de las luces by Alejo Carpentier and in Yo el supremo by Augusto Roa Bastos. 79 In the 1930s, some Marxist authors such as Peruvian writer Mariátegui, found in the Inca experience inspiration for a primitive Communism, although one without significant consequence for Marxist theory or Latin American socialist movements. .
} 
dominant trend, inspired by the classic authors of social thought based on the histories of their own countries, and another current willing to recognize the unique civilizing features in national cultures that cannot be derived from a general theory of modernization. ${ }^{80}$

This proclivity to see oneself reflected through the rose-tinted prism of the experience of central capitalist countries explains the divergent visions of modernity espoused by Latin American and European social theory. As Martuccelli points out, in classical social theory the modern experience is regarded as a tragedy: that of a human condition that has lost its guideposts in the world, along with the sustaining pillars of faith and tradition. Conversely, in Latin American social theory, modernity is an ideal to be attained, and modernization the path toward greater harmony and happiness. Put another way: in Europe, the tragedy is to be modern; in Latin America the tragedy is to think that we have failed to be modern.

Citizenship studies in Latin America undeniably are infused with an idealized vision of the modern experience and a viewpoint that defines itself through a manufactured image of what citizenship should be. Even the most developed versions of citizenship fail to transcend this vision. Let us look, for example, at Wanderley Guilherme dos Santos' concept of "regulated citizenship" which argues that the roots of citizenship "are found not in a code of political values, but in an occupational stratification system [...] defined by a legal norm." ${ }^{, 81}$

Wanderley Guilherme dos Santos is referring mainly to the key role the Employment Card (Carteira de Trabalho) played for decades in Brazil as a means of access to social rights and of symbolic and practical recognition. The concept of regulated citizenship is developed in contrast to the universal scope of "political" citizenship. However this wasn't a local deformation of the original model. The different historical incarnations of citizenship were subject to regulatory practices based on legally sanctioned forms of social stratification. In most European

\footnotetext{
${ }^{80}$ See Bernardo Sorj, A construçao intelectual do Brasil contemporâneo, part two; Sérgio Costa, As cores de Ercília; José Mauricio Domínguez, "A dialéctica da modernizaçao conservadora e a nova história do Brasil"; and Jessé Souza (ed.), O malandro e o protestante.

${ }^{81}$ See Wanderley Guilherme dos Santos, Cidadania e justicia, p. 75.
} 
countries, citizenship was initially census-based, in other words, suffrage was associated with property and income. In some cases, exclusion was based on religion and, in others, gender (it is remarkable how recently women were granted suffrage in advanced countries), or race (suffice it to say that only a few decades ago, racial segregation was governed by statute in the United States).

Social rights only achieved somewhat universal coverage in Europe after the postwar period. The Work Card was an invention of the French Revolution that subsequently was appropriated by Fascism. Likewise, in Europe in the first half of the $20^{\text {th }}$ century, social rights always were unevenly distributed between rural and urban areas and among different sectors of workers. More recently, we have only to mention the large number of "undocumenteds" currently working in Europe and the United States without the benefit of social rights and living in constant fear of imminent deportation.

Therefore, the point here is not to discuss the Brazilian experience as a case of regulated citizenship compared to a normal model of citizenship that is universal in nature, but instead to reconstruct the concept of citizenship itself, based on the Brazilian experience, as one of the possible variations on the universal problem of regulating citizenship, meaning the differential rhythms and diverse criteria that enable different sectors of the population to enjoy citizen rights.

Marcelo Neves, who has authored original works on the sociology of law, also falls into the trap of setting up direct comparisons between central and peripheral countries, when what we are dealing with is more a progression or a matter of degree. His most recent works reveal a deepening propensity to generalize excessively the Brazilian experience or to transfer it to the group of countries "on the periphery of the contemporary international system." ${ }^{\prime 82}$ Drawing from the Luhmannian model in which the legal system's features are self-contained and based on operational closure defined by the legal/illegal dichotomy, Neves argues that peripheral countries fail to preserve the autonomy of their legal system because the latter is invaded by other social codes. Thus, guiding behavioral principles such as

\footnotetext{
${ }^{82}$ See Marcelo Neves, "Et si le deuzième chameau venait à manquer?".
} 
power/no power or friend/enemy end up colonizing the legal sphere, preventing it from functioning as an autonomous subsystem and destroying the internal mechanisms through which the legal system recreates itself. The result is social practice that promotes the constant intervention in the legal process by elements external to the self-referenced system, capable of usurping the space for legality and constitutional principles.

According to Neves, the constant incursion of private interests in the legal system leads to legal inconsistency. It destroys the coherence between the legal rule and the ruling and precludes the consolidation of the legal subsystem, which constantly is being undermined by the intrusion of external forces, particularly the power of money and politics. This fuels the chaotic production of norms and regulations not contemplated in legal texts. In this context, the constitution's role as a domesticator of politics is rendered ineffective and it becomes instead a symbolic system, devoid of legal effect and used at random to legitimize ad hoc measures. Social interaction in the post-traditional world in peripheral countries, therefore, is condemned to a state of extreme unpredictability, since it exists in a context of "unchecked legal insecurity.",83

Ironically, Neves' work alludes to a posthumous publication by Luhmann, ${ }^{84}$ in which the latter acknowledges a growing trend in advanced countries to sabotage the codes underlying social subsystems, in particular the legal subsystem. The increasingly pervasive invasion of the legal system by the economic power elite is not, therefore, a phenomenon confined to peripheral countries, nor is the trend toward privatization of security systems transferring the use of force to private hands outside of law enforcement frameworks.

Taken literally, the image of a blocked Judiciary, as Marcelo Neves perceives it, confronts us with the specter of chaotic societies incapable of functioning in the capitalist market. Yet this is not the case. In peripheral societies-and taking into account the enormous variations among national situations-social subsystems

\footnotetext{
${ }^{83}$ Ibid, p. 118.

${ }^{84}$ See Niklas Luhmann, "La restitución de douizième chameau".
} 
continue to function, despite their fragility and defects. What we are seeing, then, are gradations rather than black and white situations that idealize one side while demonizing the other. In any event, a historical analysis would reveal in any country a state of continual invasion of each subsystem by the others, and reactions against such invasions, ${ }^{85}$ Italy, for instance, offers a revealing example of a political system characterized by corrupt political parties that was challenged by Operation Clean Hands, which in turn was the target of a backlash from the affected groups.

\section{Notes on Latin American Individualism}

State protection evolved very differently in Latin America. In a general sense, citizen integration revolved around the rural-urban dichotomy. Up until the1960s, rural populations across most of the continent remained almost untouched byt public services, with little or no access to the institutions of civil and political citizenship. In urban areas, the protection of the State usually reflected a divide between social sectors which enjoyed access to public services and population segments largely excluded from the distribution of State-channeled wealth.

Access to government-distributed goods, in general, was guided strongly by corporativist interest of the middle classes and organized labor, while the dominant classes, including mmany e politicians regarded the State as booty, as spoils ripe for the plundering. ${ }^{86}$ As the State gradually became more modernized, middle class sectors permeated the government apparatus and enterprises, acquiring a series of social rights that enabled them to enjoy access to public goods and privileges not available to the rest of the population, absorving a large portion of the national budget social expenditures. Finally, salaried sectors, particularly those situated in large corporations, were integrated into public policies either directly, through social benefits, or indirectly, through labor agreements that accorded them access to the services offered by government enterprises. The rest of the urban and rural population remained excluded from the resources administered by the State.

\footnotetext{
${ }^{85}$ As Albert Hirschman shows in Saída, voz e lealdade.

${ }^{86}$ See Bernardo Sorj, A nova sociedade brasileira.
} 
This vision, however, should be examined in a more nuanced way. For instance, countries such as Argentina, Uruguay, Costa Rica, and to a lesser degree, Chile - which were made up mainly of European immigrants and had no history of slavery or of subjecting the rural indigenous populations to servitude-became urbanized early on, integrated much of the population into a formal wage structure, and ensured access to urban public services and basic education, to a large part of the population. By the mid $20^{\text {th }}$ century, the social structure in those countries featured a solid middle class and lower levels of social inequality relative to the rest of the continent.

The expansion of the State in contemporary Latin America was a two-tiered process: first, it acquired more tools for optimizing economic managementmodernizing some of the government apparatus, expanding its role in production, developing infrastructure and educational, scientific, and technological systems. At the same time, it remained enormously permeable to internal colonization by dominant groups. ${ }^{87}$

In recent decades, the growing democratization of culture and social expectations, economic transformations, the waning social and political influence of the industrial working class, and pressures from the international financial system in the context of anti-inflationary policies promoting greater fiscal austerity, caused the traditional model of State colonization by dominant groups and the middle classes to implode.

The dissolution of longstanding ties based on patronage and the demise of traditional forms of domination in modern urban Latin American societies, does not necessarily imply the emergence of a type of individualism imbued with the values of respect for the public interest or for personal merit and a work ethic, as classical modernization theories assumed. Put another way, the vacuum left by the disappearance of the old traditional loyalties and hierarchical systems does not automatically engender a liberal society. While it may be possible to detect many of

\footnotetext{
${ }^{87}$ Ibid, Ch. 1.
} 
the traits described in sociological literature from the central countries in the predominant form of Latin American individualism, the latter also has specific qualities shaped by the local cultural and institutional context. Below, in summary form and using the Brazilian situation as a particular point of reference, we describe some of the specific features of individualization processes on the continent:

1) The first characteristic is hyper-reflexivity. While in central countries reflexivity and, by extension, uncertainty in social relations is played out in the sphere of intersubjective private or market-related behaviors, Latin American individuals must act under an assumption of total uncertainty on the rules of the game, even when interacting with government institutions. In other words, the world of public agencies is part and parcel of the sphere of reflexive action and uncertainty. For example, when a police officer imposes a fine, the citizen can decide whether to pay it or to attempt a bribe; when a tax is levied, he or she must evaluate whether it is more worthwhile to pay the tax or tip the taxman; a citizen who is robbed must evaluate whether or not to report the crime to the police, as this might attract the attention of crooks or kidnappers connected to the "public security forces;" he or she likewise must ponder whether it is worth pursuing a legal process, considering that the other party might try to circumvent the legal system through economic might; finally, in economic pursuits, the individual can decide whether or not to circumvent government controls and evaluates each government regulation or law mindful of the possibility of evading the legal norm. ${ }^{88}$

2) The second characteristic is that the new mechanisms of anonymous domination, forms of domination tied to personal power persist, which means that powerful groups (a generic concept which, depending on the context, may include the police or tax inspector) still have the potential to impose their will without regard for legalities, while low income sectors must accept situations of submission to authority and loss of legal rights. Both foment a lack of accountability: in the case of the dominant group, by creating incentives for impunity, and in that of the dominated

\footnotetext{
88 Obviously peripheral countries do not hold a monopoly on this situation. In the central countries, universal procedures are never totally respected across the board; in particular, dominant groups never fail to wield their influence to obtain greater impunity for their actions.
} 
group, by stimulating feelings of victimhood. If it is true that social inequality informs and transforms individualization processes in all modern societies, this is more easily discerned in peripheral countries where social inequality is extreme. A paradigmatic case is found, for example, in the presence of the domestic employee in family relations, a presence that reorganizes relative positions within the family and engenders relationships of exploitation and submission among women. ${ }^{89}$

The fact that most Latin American feminists usually have not included in their theoretical constructs and research, the central role of domestic work in the formation of gender and family relations illustrates the limits associated with transferring theoretical frameworks and struggles for rights developed in central countries.

3) In Latin America, the individualistic "presentism" of the modern condition, in other words, the search for instant gratification and the absence of a sense of history as a collective construct conferring a shared past and future, does not eliminate a sense of collective "futurism," the hope that "something" or "someone" will provide a solution to society's problems. This is evidenced in the hypertrophy of expectations deposited in the political world, in the constant danger of institutional excess given the social expectations placed in a "savior of the country" and in the feeling that the nation is re-founded following each election. ${ }^{90}$

4) There is a growing disjuncture between the international ideal standards and the national reality. As we have seen, Latin American elites, and in recent decades, the middle classes, experienced their national reality through the mirror of, and in comparison to, the central countries or, in the leftist tradition, communist

\footnotetext{
89 This obviously is not to say that men do not benefit equally from the services of the domestic worker. However, as a contemporary indicator of the increasing individualization of low income sectors and the changing sexual habits of the middle classes, we need only point out, in the Brazilian case, the virtual disappearance of the traditional practice involving the sexual initiation of adolescents with domestic workers.

90 According to Giorgio Alberti, the salient feature of Latin American politics, which he terms "movimientismo" is found in the unrealistic expectations deposited in politics, which revolve more around individual than collective interests. See "Democracy by Default; Economic Crisis, "Movimientismo" and Social Anomie in Latin America."
} 
countries. The globalization of communications - through widespread access to radio and television—democratized expectations and induced a prevailing sense of relative deprivation among virtually the entire population as one's personal or national reality was contrasted with that of more advanced countries. We live in an age of "reflexive citizenship", in which each individual looks at the relative position of his/her country in the different world scales of wealth, democracy, human development, etc.

5) Finally, because social subsystems have limited autonomy, personal networks become critical when it comes time to mobilize support against situations of institutional arbitrariness. Lasting personal relationships of dependence solidified around economic inequality and a sense of belonging to a society by default, in other words, of being caught up together in a tangled web of problems (violence, inequality, and corruption) reduces social alienation in that it discourages the tendency toward isolation between individuals, society, and culture, so characteristic of modern societies. Put another way, the powerful interpenetration of social subsystems, together with a sense of societal "chaos," have had an effect on limiting the autonomization of individuals, and, at the same time diminishing their immersion in a tragic personal subjectivity, isolated from the rest of the world. ${ }^{91}$

\footnotetext{
91 Perhaps it is no coincidence that the feeling of tragic individualization in Latin American literature is most prominent in the work of Juan Carlos Onetti, an author whose country of origin, Uruguay, presents socio-cultural characteristics that closely resembles those of central countries.
} 


\section{CONCLUSIONS - Politics without Morals and Morals without Politics?}

We are living in a moment when the main social categories of contemporary history are undergoing a rapid mutation. The workers/people versus capitalists/elites dichotomy that informed the social identities and conflicts of industrial capitalism is being attenuated or replaced by social identities and new dichotomies that are fragmented and fragment social life. Ethnicity, gender, and religion are among the many identities that currently inform people's perceptions of self and others, and their demands focus more on defending specific worlds than reconstructing society as a whole.

Social classes - the main collective actors of the $20^{\text {th }}$ century-have lost their protagonism. That is to say that class struggle and their attendant ideologies entered into decline and there is nothing to indicate a resurgence of these social categories. Nonetheless, politics goes on and the challenge for the social sciences is to decipher its logic.

As we saw at the beginning of this book, modern citizenship simultaneously developed the notion of free and equal individuals based on a national community. Citizenship was premised on the notion of individuals united by common values and projects which, while divergent and conflictive, were designed for the nation as a whole. However, individualism and the growing symbolic fragmentation occasioned by the emphasis placed on ethnic and/or religious cultures that often regard personal and/or group loyalties as non-negotiable priorities has jeopardized the republican notion of public space and the common good.

This mutation is accompanied by changes in political culture and political organizations. Instead of political parties entrusted to express inclusive visions of society, we are witnessing a fragmentation of social representation, coupled with a fragmentation of identities. NGOs have become the new purveyors of values and mini-utopias, and their proliferation goes hand in hand with the disintegration of the major ideologies. Political parties, while still irreplaceable as a mechanism for 
political-institutional representation, seem condemned to become amorphous conglomerates devoid of moral density, caught up in the maelstrom of a social world whose parameters and dynamics they no longer understand.

Human rights discourse is now the lingua franca of globalization. Its engineers are NGOs and international entities (particularly the United Nations system) and its main funding sources are international agencies, North American foundations, philanthropic organizations, and European governments. The social activists who espouse this new ideology operate on an international scale with the support of the media. In this context, the ideologues of national political parties have turned into provincial intellectuals responsible for administering a small local world and its adaptation to the realities of globalization.

The democratic paradox is evident in the debilitation of political democracy not due to a shortage of democratic values, but rather to deepened expectations of equality. The democratic values of a society that strives to be transparent and egalitarian cause suspicions concerning the morality of politicians and the opacity of the State, together with a growing frustration with political parties and a feeling that democratic governments are incapable of confronting the problems of social equality and violence. In other words, the clash between the expectations created by a democratic culture and the social and political-institutional reality is expressed in a loss of confidence in democracy itself as a political system.

Whereas before, social innovations were translated and incorporated into the major inclusive ideological frameworks, human rights operate through a process of continuous fragmentation and expansion. Each new group or new perception in society is associated with the defense of a new right (right of women, of children, of African Americans, of minorities, of animals; right to health, to information, to development; environmental rights, and so forth).

While human rights absorb everything, social conflict develops over how those rights are interpreted, and this is the terrain for the current clash between two major viewpoints. The first, clearly ethnocentric, perspective lays claim to an 
essential nucleus of human rights (mainly those ensuring individual liberty) embodying a superior world view anchored in the sacred core of "western culture." This perspective is deeply rooted in the Anglo-Saxon world and is the predominant view of the United States today. The second perspective, associated with the experience of post-colonial trauma and disseminated in recent years in continental Europe, incorporates the right to cultural diversity (with the important exception of France), and places emphasis on tolerance toward social groups that do not practice—or are even at odds with—values associated with human rights.

Both of these perspectives, as tends to be the case with all world views, are confronted with the practical problems of inclusiveness and coherence. Thus, the ethnocentric vision constantly runs the risk of dehumanizing everything that does not fit squarely into its perception of humanity, while the multicultural human rights perspective ends up equating all cultures, thereby reducing the capacity for selfdefense or struggling for one's own values.

\section{Challenges for Democracy}

Modernity breaks with all the preceding forms of society inasmuch as it no longer regards the social order as a destiny preordained by a transcendental force external to human will. In the modern world, the individual and society are condemned to selfgenerate, to invent the future. Only in modern times have the individual and society come to portray themselves as entities autonomous from other areas of social life (particularly religion), and this is what led to the emergence of new cognitive disciplines such as sociology and psychology.

The constitution of new forms of individualism and collective action paved the way for a series of rights, institutions, and ideologies that helped modern individuals become the producers of their own future. Political ideologies in the $19^{\text {th }}$ and $20^{\text {th }}$ centuries were the vector through which the collective destiny of "society" was cast into the future. Those ideologies entered into crisis when people stopped believing in progress, in the possibility of predicting the future of society, or in the likelihood that society could be shaped by political projects. 
The disjuncture between politics and society led social activists and intellectuals to develop new conceptual frameworks and organizational styles that would enable them to think up and act on new forms of societal self-transformation. This has given rise, as we have seen, to the current emphasis on categories such as "civil society" and to the development of NGOs, which mainly have served to dissociate politics (understood as participation in the public sphere with the objective of governing and/or transforming the State) from morals. Moreover, human rights discourse has dissociated the new transnational discourses from the local political dynamics, which are still organized within national States. ${ }^{92}$ This dissociation has particularly affected political parties, which have been reduced to producers of administrative bureaucrats whose legitimacy lies mainly in their capacity to keep financial stability and deliver growth. Innovative state politics was left to charismatic polititians, normally with strong authoritarian pendor.

The new political ideologies no longer portray themselves as political. ${ }^{93}$ Rather it is seen as a moral vision premised on values extracted from human rights discourse or religion. The disconnect between morals and politics, due to the State's declining legitimacy as a producer of values and the displacement of social conflict toward the Judiciary, have led contemporary social thinkers to transfer the focal point of reflection on society, shifting the analysis from the power of the State toward the production of rights.

In a world in which the triumph of individualism is accompanied by growing social inequality and signs of disintegrating bonds of social solidarity, the debate at the core of liberal tradition has shifted, in particular, toward the issue of justice in an individualistic society (Rawls' work is central here), toward the role of the Judiciary (here, Dworkin's work stands out), and toward opportunities for maintaining community-based forms of social organization in a liberal system. ${ }^{94}$

\footnotetext{
92 See Michael Ignatieff's book, Human Rights as Politics and Indolatry, which examines human rights in the sphere of international relations.

${ }_{93}$ See Richard Rorty, Achieving our Country.

${ }^{94}$ See, in particular, John Rawls, A theory of Justice; Ronald Dworkin, Los derechos en serio. Within the extensive bibliography on communitarianism, a synthesis of the debates can be found in Amy
} 
The socialist tradition, for obvious reasons, is experiencing an even more profound crisis, as it has suffered two major dislocations: first, the end of the belief in the protagonism of the working class and its potential to create a new society; and second, the sectors currently emerging as capitalism's main "victims" are not those exploited by the system, but rather those excluded from it, the chronically unemployed, the "unemployable."

The challenge for socialist parties became one of proposing programs that incorporated the new middle sectors and the values associated with new public administration methods developed in the private sector-such as efficiency, competitiveness, fiscal discipline_-while exhibiting some sensitivity towards the problems of social inequality. One of the most intellectually elaborated responses to this challenge has been the "third way," which stresses the use of public policy to ensure a baseline of social services to limit social exclusion and the deterioration of the most impoverished sectors. ${ }^{95}$ But while the "third way" recognizes that the State has a compensatory role to play, it concurs that labor market regulation should be kept to a minimum. This stance is also particularly sensitive to identitary claims or demands, an area where symbolic recognition policies could be developed at relatively little financial expense or significant harm to market functioning.

The "third way" has been portrayed as the only viable alternative from the left to date, in the context of the new globalized capitalism, able to cast its lot with the world of the "winners" without turning its back completely on values of solidarity and social justice, in other words, without neglecting the "losers." The extent to which it is possible, however, to preserve the State as a compensatory tool for social justice while allowing the "market" to intensify social inequity or destroy the social rights that have been won (such as limits on the work day, vacation, retirement, maternity rights) is still an open question, to say the least.

Gutmann, Multiculturalism; Amitai Etzioni, New Communitarian Thinking; Nathan Glazer, Affirmative Discrimination.

${ }^{95}$ See Anthony Giddens, Para além da esquerda e da dereita. 
In contrast to the "third way", other initiatives, still in their embryonic stages, attempt to revisit the revolutionary, extraparliamentary theory, associated with new forums for antiglobalization struggles. A sign of the times: the debate has shifted toward a critique of the legal system. Antonio Negri's work ${ }^{96}$ stands out in this regard; he argues in favor of stretching social boundaries by promoting constituent power over the legal forms that seek to domesticate or discipline it. Meanwhile, other currents have criticized the social order from the standpoint of legal pluralism, ${ }^{97}$ invoking the growing fragmentation of the legal system at the supra and subnational levels and stressing the need to establish new spaces for self-organization and solidarity guided by alternative values. ${ }^{98}$

There is nothing to indicate that the paths described here represent a convincing solution for reconstituting the social order. The durability of Negri's "constituent power" runs counter to the body of sociological knowledge regarding how societies tend to organize social life and is based on the author's quite idiosyncratic vision of the human condition and freedom. The "legal pluralism" analysis fails to take into account that criminals are behind most of the new forms of extra-governmental legal regulations, or they are the result of the lack of adequate government services (in the slums, for example), rather than an expression of a superior legal organizational structure.

Clearly these perspectives reflect a very real phenomenon: the crisis of citizenship as it crystallized in the $20^{\text {th }}$ century. Citizenship is the institutional mechanism through which the legal system coordinates the relationships between itself, society, and the State in modern democratic societies. Nonetheless, the components of this equation today are substantially different. "Society," as a human grouping empirically and subjectively identifiable with a population defined by national borders has lost its density, either because of globalization processes or new collective identities that are not confined by national frameworks. The State, while maintaining its central role in social regulation, has lost legitimacy due to the

\footnotetext{
${ }^{96}$ Antonio Negri, O poder constituinte.

${ }^{97}$ There is a vast amount of literature on legal pluralism; see Jean Carbonier, Sociologie juridique. Regarding the debate over the utilization of the Brazilian case, see Eliane Botelho Junqueira, $A$ Sociología do Direito no Brasil.

${ }^{98}$ See, in particular, Boaventura de Souza Santos, Toward a New Conventional Wisdom.
} 
dwindling representativity of political parties or faltering loyalty to the fatherland/nation/people, in addition to the pervasive sense that governance has become a technocratic exercise at the service of market demands. Lastly, the legal sphere has been undermined by the impact of the constitutionalization of the legal system and the influence of human rights on legal practice, by the expansion of the legal field to incorporate new subjects, and by the judicialization of social conflict.

Citizenship as the principal vector of participation and political representation entered into crisis, bringing into sharp relief the growing communication gap between the various social subsystems and the State. As we have seen, the new collective identities, and the social actors associated with them (affiliated with networks operating at a sub or supra-State level), ${ }^{99}$ do not aspire to government and generally promote transnational agendas. As the judicial system absorbs this new reality, it must accept the de-coupling of the national State system and the legal system, which ultimately dissociates citizenship from the national legal system. Likewise, the development of new social actors around social identities that accentuate their essential differences carries with it the risk of destroying the public space, understood as a substratum of common values premised on the belief that the debate established in the public sphere is productive, in other words, that it transforms those who engage in it, has substantive value, and is not merely a negotiating field for individualistic or corporativists interests or visions.

Perhaps the main contradiction of public life in the contemporary world lies in the universalization of homogenous political and economic agendas at a time when national states -with very different social structures and cultural traditionscontinue to be the locus for the generation and distribution of wealth. The universalization of agendas insensitive to national differences is as prevalent among those who embrace the so-called neoliberal policies as it is among those who oppose them. The difference is that those who regard globalization as positive uphold a free market agenda, while their opponents support the promotion of their similarly homogeinizing agenda worldwide.

\footnotetext{
${ }^{99}$ See Manuel Castells, The Rise of The Network Society.
} 
The trend toward global agendas and postures that tend to bypass the State opens the door to populist or to extreme right-wing politicians who claim to represent and defend the nation. With such trends in mind, this work points to the need to go beyond globalized agendas. It underscores the urgent need to develop national institutional strategies that unhesitantly incorporate the globalized context and act on it, while strengthening the State as a democratic instrument for the regulation and control of economic power, reinventing social policies and labor law instruments, and creatively reestablishing the connection and balances between individual and collective rights, since it is impossible to create individual paradises while living in urban social infernos. This challenge requires us to reject postures that view globalization as a schizophrenic phenomenon: with a dark side to be eliminated and a good side to be cultivated. Instead, we must keep in mind that, in capitalism, the lex mercatoria has always prevailed and that it is up to social forces to take advantage of the transformative momentum of capital to demarcate its empire and humanize its impact. 


\section{ANNEX: A Note on the Interdisciplinary Approach}

The author of this essay is conscious of both the need for and the limitations of an interdisciplinary approach which is, in a way, a kind of social science utopia. There is some consensus around the notion that the resources found in various disciplines must be mobilized in order to understand the complexity of social life, as each one is only able to reflect exclusively on a partial dimension of society. However, when the utopian interdisciplinary effort is actually carried out, the outcomes often fall short of the expectations. What occurs is a sort of bricolage, in which different disciplines are moved about in an ad hoc fashion to fill in the gaps left by the others. What is obtained, in the best case scenario, is a prime work that is impossible to replicate as it is the unique product of the author's intellect or capacity for synthesis. Therefore, while studies within a single discipline are, in large part, redundant, inasmuch as their lengthy arguments only serve to confirm the state of the arts, interdisciplinary works frequently are entropic, in other words, impossible to reproduce, as they lack theoretical consistency and offer no effective opportunities for comparison or intellectual accumulation.

The difficulty of the interdisciplinary approach is two-fold in that specialization is an expression of the reality of modern societies with highly differentiated social subsystems, and also reflects the variety of disciplines that study those subsystems and develop theories, concepts, and issues and-even more importantly-self-refered discourses that render the passage from one disciplinary framework to another a dubious proposition.

The main problem with the interdisciplinary approach is not that each social science discipline has a privileged focus, and relates to other disciplines in a many times invasive, disrespectful, or, as is often the case, insensitive posture toward the ir theoretical and practical specificities. However the main difficulty in advancing an interdisciplinary approach lies in the fact that in a democratic society the autonomy of social subsystems is the prerequisite for intellectual pluralism, individual and collective freedom and the basis for a justice system that is not subjected to the 
tyranny of economic, political, cognitive, or religious power. In this sense, any explanatory system that seeks, for instance, to reduce the law (or any other social subsystem including scientific research) to exogenous causes such as, for example, economic interests or some other external factor, is party, consciously or not, to an effort to delegitimize democratic institutions.

If we decided to undertake an interdisciplinary analysis beginning with recognition of these difficulties, it is because we believe that the social dynamics of today compel a dialogue among disciplines. Furthermore, this dialogue must reflect and operate on a reality in which the boundaries between the legal system and other social subsystems are, if not evaporating, at least exhibiting clear signs of countless cracks and tensions. This doesn't mean that the erasing of borders between subsystems should be welcomed. In contemporary Latin America, the sense of urgency created by inequality and the immense social problems continues to lead many change-seeking social scientists to support transformations that bypass legal procedures and the inherent requirements of legal principles. Such approach fall into the same tendency, deeply rooted in the history of the continent, that fails to understand that democracy can only be built upon the recognition of, and respect for, the intrinsic rules of each social subsystem. 


\section{Bibliography}

ALBERTI, Giorgio, "Democracy by Default, Economic Crisis, "Movimientismo" and Social Anomie in Latin America." Work prepared for a presentation at the XV World Congress of the International Political Science Association, Buenos Aires, 1991.

APPADURAI, Arjun, The social life of things, Cambridge, University Press, 1996.

ARANTES, Rogério B., Judiciário e política no Brasil, São Paulo, Sumaré, 1997.

ARATO, Andrew, "Além da dicotomia Estado/Mercado", Novos Estudos CEBRAP, n.36, 1993.

"Uma reconstituição hegeliana da sociedade civil", in AVRITZER, Leo (ed.), Sociedade civil e democratização, Belo Horizonte, Del Rey, 1994.

BAUDRILLARD, Jean, Le système des objets, Paris, Gallimard, 1968.

BAUMAN, Zygmunt, Legislators and interpreters: on modernity, postmodernity, and the intellectuals, Oxford, Polity Press, 1987.

Intimations of postmodernity, London, Routledge, 1992

Life in fragments, Oxford, B lackwell, 1995.

Zahar, 1999.

O Mal-estar da pós-modernidade, Rio de Janeiro, Jorge

BECK, Ulrich, What is globalization?, Oxford, Blackwell, 2000.

BOBBIO, Norberto, O conceito de sociedade civil, Rio de Janeiro, Graal, 1982.

A era dos direitos, Rio de Janeiro, Campus, 1992.

BOBBIT, Phillip, The shield of Achilles: war, peace and the course of history, London, Penguin, 2002.

BOROUMAND, Ladan, La guerre des principes. Paris, Editions de L'École des Hautes Études en Sciences Sociales, 1999.

BULMER, Martin e Anthony M. REES (orgs.), Citizenship today: the contemporary relevance of T. H. Marshall, London, UCL Press, 1996.

CARBONNIER, Jean, Sociologie juridique. Paris, PUF, 1978.

CASTEL, Robert e Claudine HAROCHE, Propriété privée, propriété sociale, propriété de soi, Paris, Fayard, 2001.

CASTELLS, Manuel, The rise of the Network Society, Oxford, Blackwell, 1996. 
COHEN, Jean e Andrew ARATO, Civil society and poltical theory, Cambridge, MIT Press, 1997.

COLEMAN, James M., Foundations of social theory, Cambridge, Harvard University Press, 1990.

CORTEN, Olivier e Patricio NOLASCO, "Pluralism culturel, pluralism juridique et démocratie: les ambigúites du discours identitaire zapatiste", Les Cahiers du GELA.IS n.1, 2001.

COSTA, Sérgio, "A construção da raça no Brasil", ms.

As Cores de Ercília. Belo Horizonte, UFMG, 2002.

DEZALAY, Yvez, GARTH, Bryant G., The Internationalization of Palace Wars -Lawyers, Economists, and the Contest to Transform Latin American States, Chicago, The University of Chicago Press, 2002

DOMINGUES, José Maurício, "A dialética da modernização conservadora e a nova história do Brasil", DADOS, n.3, v.45, p.459-482, 2002.

DOUGLAS, Mary e Baron ISHERWOOD, The world of goods, London, Routledge, 1996.

DWORKIN, Ronald, Los derechos en serio, Barcelona, Ariel, 1999.

EHRENBERG, Alain, La fatigue d'être soi, Paris, Odile Jacob, 1998.

ETZIONI, Amitai, New Communitarian Thinking, Charlottesville, The University Press of Virginia, 1996.

EWALD, François, Histoire de l'état providence, Paris, Grasset, 1986.

FEATHERSTONE, Mike. Consumer, culture \& postmodernism, London, Sage, 1990

FERNANDES, Rubem César, "Threads of Planetary Citizenship", in OLIVEIRA, Miguel D. e Rajesh TANDON (orgs.). CitizensStrengthening global civil society. Washington, Civicus, 1994.

FERRY, Luc e Alain RENAUT, Philosophie politique: des droits de l'homme à l'idée républicaine. Paris, PUF, 1985.

FRASER, Nancy, "Da redistribuição ao reconhecimento? Dilemas da justiça na era pós socialista", in SOUZA, J. (org.). Democracia hoje: novos desafios para a teoria democrática contemporânea. Brasília, UnB, 2001.

FROMM, Erich, Escape from freedom, New York, Henry Holt, 1995.

GABRIEL, Yannis e Tim LANG, The unmanageable consumer, London, Sage, 1995

GAUCHET, Marcel, "Essai de psychologie contemporaine", Le Débat, ns.99 e 100, 1998.

La religion dans la démocratie: parcours de la laïcité. Paris, Gallimard, 1998.

"Quand les droits de l'homme deviennent une politique", Le Debat, n.110, mai-out, 2000. 
GIDDENS, Anthony, Para além da esquerda e da direita, São Paulo, Unesp, 1995.

and Scott LASH, . Reflexive modernization, Stanford, Stanford University Press, 1994

GLAZER, Nathan, Affirmative discrimination: ethnic inequality and public policy. Cambridge, Harvard University Press, 1987.

GROS, Christian, Políticas de la etnicidad: identidad, estado y modernidad, Bogotá, ARFO, 2000.

HABERMAS, Jürgen, The theory of communicative action, Boston, Beacon Press, 1989.

"Struggles for recognition in the democratic constitutional state", in GUTMANN, Amy. Multiculturalism, Nona Jérsei, Princeton University Press, 1994.

HIRSCHMAN, Albert, Saída, voz e lealdade. São Paulo, Perspectiva, 1970.

HUNTINGTON, Samuel, Political order in changing societies, London, Yale University Press, 1969.

IGNATIEFF, Michael. Human rights as politics and idolatry, Princeton, Princeton, 2002.

JUNQUEIRA, Eliane B., A sociologia do direito no Brasil, Rio de Janeiro, LumenJuris, 1993.

KAGAN, Robert, Of paradise and power: America and Europe in the new world order, New York, Knof, 2003.

LASCH, Christopher, The minimal self: psychic survival in troubled times, New York, Norton, 1984.

LEFORT, Claude, L'Invention democratique: les limits de la dominiation totalitaire, Paris, Fayard, 1981.

LUHMANN, Niklas, "La restitution du douzième chameau: du sens de'une analyse sociologique du droit", Droit et Societé, n.47, 2001.

MACPHERSON, C. B., The political theory of possessive individualism, Oxford, Oxford U.O., 1962c

MANN, Michael, "Ruling Class Strategies and Citizenship", Sociology, vol. 21, n. 3, 1987.

MARSHALL, T. H., Citizenship and social class and other essays. Cambridge, Cambridge University Press, 1950.

MARTUCCELLI, Danilo, "Del espejo opaco a los riesgos de la transparencia invisible: notas sobre la teoría social", ms., 2002.

Dominations ordinaries, Paris, Balland, 2002.

Grammaires de I'individu. Paris, Gallimard, 2002.

MARX, K.arl, El Capital, V.1, Buenos Aires, Cartago, 1973. 
McCRACKEN, Grant. Culture \& consumption, Bloomington, Indiana University Press, 1990.

MILLER, Daniel (org.)., Acknowledging consumption, London, Routledge, 1996.

NEGRI, Antonio, O poder constituinte, Rio de Janeiro, DP\&A, 2002.

NEVES, Marcelo, "Et si le douzième chameau venait à manquer? Du droit expropiateur au droit envahi", Droit et Societé, n.47, 2001.

OLIVEIRA, Dayse, Research Sites and Researchers on Civil Society and NGOs, The Edelstein Center for Social Research, Research Resources on Internet, Report No.1, 2005. www.centroedelstein.org.br/report/Report civil society.pdf PERALVA, Angelina, Violência e democracia, São Paulo, Paz e Terra, 2000.

PIORE, Michael P., Beyond individualism, Cambridge, Harvard University Press, 1995.

PUTNAM, Robert D., Making democracy work, New Jersey, Princeton University Press, 1993.

RAWLS, John, A theory of justice, Cambridge, Harvard University Press, 1971.

RORTY, Richard, Achieving our country: Leftist thought in twentieth-century America, Cambridge, Harvard University Press, 1998.

ROSANVALLON, Pierre, La crise de l'état-providence. Paris, Seuil, 1984. La nouvelle question sociale, Paris, Seuil, 1995.

SALAMAN, Lester M. et al., La Sociedad Civil Global: las dimensiones del sector no lucrativo, Bilbao, Fundación BBVA, 1999.

SANTOS, Boaventura Souza, Toward a new conventional wisdom, London, Routledge, 1995.

SANTOS, Wanderley Guilherme dos, Cidadania e justiça: a política social na ordem brasileira, Rio de Janeiro, Campus, 1979.

SCHNAPPER, Dominique, La communauté des citoyens, Paris, Gallimard, 1994.

SIMMEL, Georg, The philosophy of money, London, Routledge, 1991.

SLATER, Don, Consumer, culture \& modernity, Cambridge, Polity Press, 1997

SORJ, Bernardo, "Crises e horizontes das ciências sociais na América Latina", Novos Estudos Cebrap, n.23, p.154-163, 1989.

A nova sociedade brasileira, Rio de Janeiro, Jorge Zahar, 2000.

A construção intelectual do Brasil contemporâneo, Rio de Janeiro, Jorge Zahar, 2001.

"La relación público/privado en el Brasil", in WOLF, L.; GONZÁLEZ, P. e NAVARRO, J.C., Educación privada y política 
pública en América Latina. Santiago de Chile, Preal/BID, 2002, p.143-184.

brazil@digitaldivide.com - Confronting Inequality in the Information Society-, Brasília, /UNESCO, 2003.

Civil Societies North-South Relations: NGOs and dependency,

The Edelstein Center for Social Research, Working Paper No. 1, 2005.

www.bernardosorj.com/pdf/Sorj_Article.pdf

SOUZA, Jessé (org.), O Malandro e o Protestante. Brasília, UnB, 1999.

SULKUNEN, Pekka, John HOLMWOOD, Hilary RADNER e Gerhard SCHULZE (orgs.), Constructing the new consumer society, London, Macmillan, 1997.

SUPIOT, Alain, Critique du droit du travail. Paris, PUF, 1994.

SVAMPA, Maristella, El dilema argentino: civilización o barbarie, Buenos Aires, El cielo por asalto, 1994.

TERRADAS, Ignaci, "Familia y ciudadanía en la Revolución Francesa". Barcelona, M.S., 1997.

TORRE, Juan Carlos, El processo político de las reformas económicas en América Latina, Buenos Aires, Paidós, 1998.

TOURAINE, Alain, Critique de la modernité. Paris, Fayard,1992. 22, maio, 2000.

"O campo político de FHC", Tempo Social. V.12, n.1, p.3-

TURNER, Bryan S., "Outline of a Theory of Citizenship", Sociology, v.21, n.3, 1987.

VIANNA, Luiz Werneck et al., Corpo e alma da magistratura brasileira, Rio de Janeiro, Revan/luperj, 1997.

WALZER, Michael, Spheres of justice. Oxford, Martin Robertson, 1983.

"Multiculturalism and the Politics of Interest", in BIALE, David, Michael GALCHINSKY e Susannah HESCHEL (orgs.), Insider/Outsider, American Jews and multiculturalism, Berkeley, University of California Press, 1998, p.89.

www.worldbank.org/civilsociety

www.worldbank.org/wbp/scapital

www.worldbank.org/wbp/scapital/topic 